\title{
Comparative Pharmacological Profiles of Morphine and Oxycodone under a Neuropathic Pain-Like State in Mice: Evidence for Less Sensitivity to Morphine
}

\author{
Minoru Narita*,', Atsushi Nakamura', Masahiko Ozaki', Satoshi Imai', Kan Miyoshi', Masami Suzuki' and \\ Tsutomu Suzuki*, I \\ 'Department of Toxicology, Hoshi University School of Pharmacy and Pharmaceutical Sciences, Shinagawa-ku, Tokyo, Japan
}

\begin{abstract}
The present study was undertaken to investigate pharmacological actions induced by morphine and oxycodone under a neuropathic pain-like state. In the $\mu$-opioid receptor (MOR) binding study and G-protein activation, we confirmed that both morphine and oxycodone showed MOR agonistic activities. Mice with sciatic nerve ligation exhibited the marked neuropathic pain-like behavior. Under these conditions, antinociception induced by subcutaneously (s.c.) injected morphine was significantly decreased by sciatic nerve ligation, whereas s.c. injection of oxycodone produced a profound antinociception in sciatic nerve-ligated mice. There were no significant differences in spinal or supraspinal antinociception of morphine and oxycodone between sham operation and nerve ligation. Moreover, either morphine- or oxycodone-induced increase in guanosine-5'-0-(3-thio) triphosphate $\left(\left[{ }^{35} \mathrm{~S}\right] \mathrm{GTP} \gamma \mathrm{S}\right)$ binding in the spinal cord, periaqueductal gray matter and thalamus in sciatic nerve-ligated mice was similar to that in sham-operated mice. Antinociception induced by s.c., intrathecal, or intracerebroventricular injection of the morphine metabolite morphine-6-glucuronide (M-6-G) was significantly decreased by sciatic nerve ligation. Furthermore, the increase in the G-protein activation induced by M-6-G was eliminated in sciatic nerve ligation. In addition, either morphine- or oxycodone-induced rewarding effect was dramatically suppressed under a neuropathic pain-like state. The increased $\left[{ }^{35} \mathrm{~S}\right] \mathrm{GTP} \gamma \mathrm{S}$ binding by morphine or oxycodone was significantly lower in the lower midbrain of mice with sciatic nerve ligation compared with that in control mice. These findings provide further evidence that oxycodone shows a profound antinociceptive effect under a neuropathic pain-like state with less of a rewarding effect. Furthermore, the reduction in G-protein activation induced by M-6-G may, at least in part, contribute to the suppression of the antinociceptive effect produced by morphine under a neuropathic pain-like state.
\end{abstract}

Neuropsychopharmacology (2008) 33, I097-I I 2; doi:I0.1038/sj.npp. I30 I47I; published online 27 June 2007

Keywords: oxycodone; morphine; M-6-G; neuropathic pain; antinociception; rewarding effect

\section{INTRODUCTION}

Most of the opioids used clinically have been classified as $\mu$-opioid receptor (MOR) agonists, including morphine and fentanyl. However, recent studies have shown that these MOR agonists and metabolites have interesting pharmacological differences (Peckham and Tratnor, 2006; Lemberg et al, 2006a,b). Oxycodone has been in clinical use since 1917. Oxycodone, which is a semisynthetic opioid analgesic derived from the naturally occurring alkaloid, thebain, has good oral bioavailability and seems to provide analgesic action that is as potent as that of morphine. It has been

*Correspondence: Professor M Narita and Professor T Suzuki, Department of Toxicology, Hoshi University School of Pharmacy and Pharmaceutical Sciences, 2-4-4I Ebara, Shinagawa-ku, Tokyo I42-850 I, Japan, Tel: +8I 35498 5628, Fax: + 8135498 583I,

E-mails: narita@hoshi.ac.jp and suzuki@hoshi.ac.jp

Received 6 October 2006; revised 13 April 2007; accepted II May 2007 demonstrated that both oxycodone and its active metabolite showed MOR agonistic activities (Lemberg et al, 2006a). Several clinical studies have suggested that oxycodone may be useful for the treatment of neuropathic pain (Watson and Babul, 1998; Satthl et al, 2006). Although oxycodone has been clinically used for many years, its pharmacological properties are still very poorly characterized.

A growing body of clinical evidence suggests that when opioid analgesics including morphine are used to control pain in patients, psychological dependence is not a major concern. We previously reported that morphine failed to induce rewarding effects in rats that had been injected with formalin or carrageenan into the hind paw (Suzuki et al, 1996, 1999, 2001; Narita et al, 2005a). Furthermore, it has been documented that chronic pain attenuates the development of tolerance to the antinociceptive effect of morphine in rats (Vaccarino et al, 1993). These findings suggest the possibility that pain could lead to physiological 
changes at supraspinal levels associated with the suppression of opioid dependence.

Neuropathic pain can elicit abnormal pain characterized in part by hyperalgesia, so that noxious stimuli are perceived as more painful and allodynia. Neuropathic pain is particularly difficult to treat clinically, as it is only partially relieved by high doses of morphine. Many studies have focused on the long-term changes in the functions of the spinal cord dorsal horn neurons, which include some receptors, protein kinases, and peptides, following nerve injury (Nichols et al, 1995; Mayer et al, 1999; Narita et al, 2000). However, the mechanism of the reduced sensitivity to morphine-induced antinociceptive effect under a neuropathic pain is not fully understood.

The aim of the present study was to further compare pharmacological profiles of morphine and oxycodone following sciatic nerve ligation and investigate the mechanisms underlying less sensitivity to morphine under a neuropathic pain-like state.

\section{MATERIALS AND METHODS}

The present study was conducted in accordance with the Guiding Principles for the Care and Use of Laboratory Animals Hoshi University, as adopted by the Committee on Animal Research of Hoshi University. Every effort was made to minimize the numbers and any suffering of animals used in the following experiments.

\section{Animals}

Male ICR mice (20-25g) and male guinea pig (250-300 g) (Tokyo Laboratory Animals Science Co. Ltd, Tokyo, Japan) were used in the present study. Animals were housed in a room maintained at $22 \pm 1^{\circ} \mathrm{C}$ with a $12 \mathrm{~h}$ light-dark cycle. Food and water were available ad libitum. Each animal was used only once.

\section{Receptor Binding Assay}

For membrane preparation, the mouse brain without cerebellum and the guinea pig cerebellum were quickly removed after decapitation, and rapidly transferred to a tube filled with an ice-cold buffer. The homogenate was centrifuged at $4^{\circ} \mathrm{C}$ for $10 \mathrm{~min}$ at $1000 \mathrm{~g}$ and the surpernatant was centrifuged at $4^{\circ} \mathrm{C}$ for $20 \mathrm{~min}$ at $48000 \mathrm{~g}$. The pellet was resuspended at $4{ }^{\circ} \mathrm{C}$ for $20 \mathrm{~min}$ at $48000 \mathrm{~g}$. The resulting pellet was resuspended and retained as membrane fraction. The $\mu$-, $\delta$-, or $\kappa$-opioid receptor (KOR) binding assays were performed in duplicate with [tylosil-3,5-(3)H(N)][D-Ala (2),N-MePhe(4),Gly-ol(5)] enkephalin ( $\left[{ }^{3} \mathrm{H}\right]$ DAMGO) (specific activity, $59.0 \mathrm{Ci} / \mathrm{mmol}$; Amersham Biosciences, Arlington Heights, IL) at $1 \mathrm{nM}$, (2-D-penicillamine, 5-Dpenicillamine)-enkephalin ([ $\left.\left.{ }^{3} \mathrm{H}\right] \mathrm{DPDPE}\right)$ (specific activity, 45.0 Ci/mmol; PerkinElmer Life science, Arlington Heights,

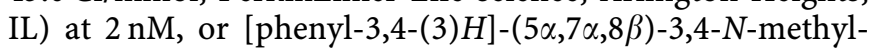
$\mathrm{N}$-[7-(1-pyrrolidinyl)-1-oxaspiro[4,5]dec-8-yl]-benzeneacetamide $\left(\left[{ }^{3} \mathrm{H}\right] \mathrm{U} 69,593\right)$ (specific activity, $41.7 \mathrm{Ci} / \mathrm{mmol}$; PerkinElmer Life science, Arlington Heights, IL) at $2 \mathrm{nM}$ in a final volume of $1.0 \mathrm{ml}$ that contained $50 \mathrm{mM}$ Tris- $\mathrm{HCl}$

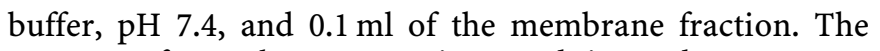
amount of membrane proteins used in each assay was in the range of $90-140 \mu \mathrm{g}$, as determined by the method of Narita et al (2001a). The test tubes were incubated for $1 \mathrm{~h}$ at $25^{\circ} \mathrm{C}$. Specific binding was defined as the difference in bindings observed in the absence and presence of $1 \mu \mathrm{M}$ unlabeled DAMGO, DPDPE, or U50,488. Incubation was terminated by collecting membranes on Whatman GF/B filters using a Brandel cell harvester. The filters were then washed three times with $5 \mathrm{ml}$ Tris- $\mathrm{HCl}$ buffer, $\mathrm{pH}$ 7.4, at $4^{\circ} \mathrm{C}$ and transferred to scintillation vials. Then, $4 \mathrm{ml}$ of clear-sol 2 (Nacalaitesque Inc. Kyoto, Japan) was added to the vials. After a $12 \mathrm{~h}$ equilibration period, radioactivity in the samples was determined in a liquid scintillation analyzer.

\section{Guanosine-5'-o-(3-thio) Triphosphate Binding Assay}

For membrane preparation, the mouse spinal cord, thalamus, periaqueductal gray matter (PAG), a section of the lower midbrain that included the ventral tegmental area (VTA), which described previously (Ozaki et al, 2004), and the guinea pig cerebellum were quickly removed after decapitation, and rapidly transferred to a tube filled with ice-cold buffer. The membrane homogenate $(3-8 \mu \mathrm{g}$ protein/assay) was prepared as described previously (Narita et al, 2001b) and incubated at $25^{\circ} \mathrm{C}$ for $2 \mathrm{~h}$ in $1 \mathrm{ml}$ of assay buffer with various concentrations of each agonist, $30 \mu \mathrm{M}$ guanosine- $5^{\prime}$-diphosphate (GDP) and $50 \mathrm{pM}$ guanosine$5^{\prime}-o$-(3-thio) triphosphate $\left.\left({ }^{35} \mathrm{~S}\right] \mathrm{GTP} \gamma \mathrm{S}\right)$ (specific activity, $1000 \mathrm{Ci} / \mathrm{mmol}$; Amersham, Arlington Heights, IL, USA). The reaction was terminated by filtration using Whatman GF/B glass filters (Brandel, Gaithersburg, MD, USA) that had been presoaked in $50 \mu \mathrm{M}$ Tris-HCl, $\mathrm{pH} 7.4$, and $5 \mu \mathrm{M} \mathrm{MgCl}_{2}$ at $4{ }^{\circ} \mathrm{C}$ for $2 \mathrm{~h}$. The filters were washed three times with $5 \mathrm{ml}$ of ice-cold Tris- $\mathrm{HCl}$ buffer, $\mathrm{pH} \mathrm{7.4,} \mathrm{and} \mathrm{then} \mathrm{transferred} \mathrm{to}$ scintillation-counting vials containing $0.5 \mathrm{ml}$ of Soluene- 350 (Packard Instrument Co., Meriden, CT, USA) and $4 \mathrm{ml}$ of Hionic Fluor (Packard Instrument Co.) and equilibrated for $12 \mathrm{~h}$. The radioactivity in the samples was determined with a liquid scintillation analyzer. Nonspecific binding was measured in the presence of $10 \mu \mathrm{M}$ unlabeled GTP $\gamma$ S. In the present study, sample preparation was performed 7 days after partial sciatic nerve-ligation.

\section{Neuropathic Pain Model}

The mice were anesthetized with sodium pentobarbital $(70 \mathrm{mg} / \mathrm{kg}$, i.p.) or $3 \%$ isoflurene. We produced a partial sciatic nerve injury by tying a tight ligature with a $8-0$ silk suture around approximately one-third to one-half the diameter of the sciatic nerve on the right side (ipsilateral side) under a light microscope (SD30, Olympus, Tokyo, Japan) as described previously (Seltzer et al, 1990; Malmberg and Basbaum, 1998). In sham-operated mice, the nerve was exposed without ligation. We previously reported that the sciatic nerve-ligated mice exhibit the thermal hyperalgesia and the mechanical hyperalgesia on the ipsilateral side, indicating the state of neuropathic pain hypersensitivity. These persistent painful states caused by sciatic nerve ligation lasted for more than 15 days (Narita et al, 2005b). 


\section{Inflammatory Pain Model}

A persistent inflammatory pain model was produced by unilateral intraplantar injection of complete Freund's adjuvant (CFA; Mycobacterium tuberculosis; Sigma, St Louis, MO, USA) in $20 \mu \mathrm{l}$ into the plantar surface of the right hind paw (ipsilateral side) of mice under the anesthesia with sodium pentobarbital $(70 \mathrm{mg} / \mathrm{kg}$, i.p.) or $3 \%$ isoflurene (Ohsawa et al, 2000). The control mice were given saline into the plantar surface of the right hind paw.

\section{Intrathecal Injection}

Intrathecal (i.t.) administration was performed following the method described previously (Hylden and Wilcox, 1980) using a $25-\mu 1$ Hamilton syringe with a 30 -gauge needle. The injection volume was $4 \mu \mathrm{l}$ for each mouse. Each solution was injected without injection cannulae.

\section{Intracerebroventricular Injection}

Intracerebroventricular (i.c.v.) administration was performed following the method described previously with modifications (Haley and McCormick, 1957; Narita et al, 2003). To make a hole in the skull for injection, 1 day before the administration of each drug, mice were briefly anesthetized with ether and a 2-mm double-needle (tip: $27 \mathrm{G} \times 2 \mathrm{~mm}$ and base: $22 \mathrm{G} \times 10 \mathrm{~mm}$, Natsume Seisakusyo Co. Ltd, Tokyo, Japan) attached to a 25- $\mu$ l Hamilton microsyringe was inserted into a unilateral injection site using a V-shaped holder to hold the head of the mouse. The unilateral injection site was approximately $2 \mathrm{~mm}$ from either side of the midline between the anterior roots of the ears. On the day of the tail-flick assay, the head of the mouse was held against a V-shaped holder and the drugs were injected into the hole. The injection volume was $4 \mu \mathrm{l}$ for each mouse. Each solution was injected without injection cannulae.

\section{Measurement of Thermal Hyperalgesia}

To assess the sensitivity to thermal stimulation, each of the hind paws of mice was tested individually using a thermal stimulus apparatus (UGO-BASILE, Biological research apparatus, VA, Italy). The intensity of the thermal stimulus was adjusted to achieve an average baseline paw withdrawal latency of approximately 8-10 s in naive mice. Only quick hind paw movements (with or without licking of the hind paws) away from the stimulus were considered to be a withdrawal response. Paw movements associated with locomotion or weight shifting were not counted as a response. The paws were measured alternating between the left and right with an interval of more than $3 \mathrm{~min}$ between measurements. The latency of paw withdrawal after the thermal stimulus was determined as the average of three measurements per paw.

\section{Assessment of Antinociception}

Antinociception induced by oxycodone or morphine was determined by the tail-flick test (Tail Flick Analgesia Meter Model MK 330B, Muromachi Kikai Co. Ltd, Tokyo, Japan).
The intensity of the heat stimulus was adjusted, so that the animal flicked its tail after 3-5s. When the intensity of stimulation was enough to produce a basal movement within $3-5 \mathrm{~s}$ in mice, it was defined that pharmacological observation results from the spinal reflex and supraspinal modulations (Le Bars et al, 2001). The inhibition of this tail-flick response was expressed as a percentage of the maximum possible effect (\%MPE), which was calculated as $\left(\left(\mathrm{T}_{1}-\mathrm{T}_{0}\right) \times 100 /\left(\mathrm{T}_{2}-\mathrm{T}_{0}\right)\right)$, where $\mathrm{T}_{0}$ and $\mathrm{T}_{1}$ were the tail-flick latencies before and after the administration of each MOR agonist and $\mathrm{T}_{2}$ was the cut-off time (set at $10 \mathrm{~s}$ ) in the tests to avoid injury to the tail. In the present study, the antinociceptive assay was performed 7 days after partial sciatic nerve-ligation. Each group consisted of 8-11 mice.

\section{Place Conditioning}

Place conditioning studies were conducted using a shuttle box $(15 \times 30 \times 15 \mathrm{~cm}, \mathrm{w} \times 1 \times \mathrm{h})$ that was made of an acrylic resin board and divided into two equal-sized compartments. One compartment was white with a textured floor and the other was black with a smooth floor to create equally inviting compartments. The place-conditioning schedule consisted of three phases (pre-conditioning test, conditioning, and post-conditioning test). The pre-conditioning test was performed as follows: the partition separating the two compartments was raised to $7 \mathrm{~cm}$ above the floor, a neutral platform was inserted along the seam separating the compartments, and mice that had not been treated with either drugs or saline were then placed on the platform. The time spent in each compartment during a 900 -s session was then recorded automatically using an infrared beam sensor (KN-80, Natsume Seisakusyo Co. Ltd, Tokyo, Japan). Immediately after subcutaneously (s.c.) injection of morphine $(3-10 \mathrm{mg} / \mathrm{kg})$ or oxycodone $(0.3-$ $3 \mathrm{mg} / \mathrm{kg}$ ), these animals were placed in the compartment opposite that in which they had spent the most time in the pre-conditioning test for $1 \mathrm{~h}$. On alternate days, these animals received vehicle and were placed in the other compartment for $1 \mathrm{~h}$. On the day after the final conditioning session, a post-conditioning test that was identical to the pre-conditioning test was performed.

\section{Drugs}

The drugs used in the present study were morphine hydrochloride (Daiichi-Sankyo Co., Tokyo, Japan), oxycodone hydrochloride (a kind gift from Shionogi Pharmaceutical Co. Inc., Osaka, Japan), morphine-6-glucuronide (M-6-G) (Sigma-Aldrich Co., St Louis, MO, USA), [D-Ala ${ }^{2}$, $\mathrm{N}$-Me-Phe ${ }^{4}, \mathrm{Gly}^{5}$-ol] enkephalin (DAMGO; Sigma-Aldrich Co., St Louis, MO, USA), (+ )-4-[( $\alpha \mathrm{R})-\alpha-((2 S, 5 \mathrm{R})-4$-allyl2,5-dimethyl-1-piperazinyl)-3-metyoxybenzyl]- $N, N$-diethylbenzamide] (SNC80; Tocris Cookson Ltd, Ballwin, MO, USA), (-)trans-(1S,2S)-U-50,488 (U50,488; Sigma-Aldrich Co., St Louis, MO, USA), ICI 199,441 hydrochloride (Tocris Cookson Ltd, Ballwin, MO, USA), $\beta$-funaltrexamine hydrochloride $(\beta$-FNA), naltrindol hydrochloride (NTI; Tocris Cookson Ltd, Ballwin, MO, USA) and nor-binaltrophimine dihydrochloride (nor-BNI; Tocris Cookson Ltd, Ballwin, MO, USA). All drugs were dissolved in $0.9 \%$ physiological 
saline (Otsuka Pharmaceutical Co. Inc., Tokyo, Japan) for in vivo experiments or assay buffer for in vitro experiments.

\section{Statistical Analysis}

The data for antinociceptive response were shown as the mean \pm SEM of $\%$ MPE. The data for $\left[{ }^{35} \mathrm{~S}\right] \mathrm{GTP} \gamma \mathrm{S}$ binding assay were expressed as the mean \pm SEM of $\%$ Stimulation. Receptor binding curves were fitted using the GraphPad Prism 4.0 program. The statistical significance of differences between the groups was assessed with a two-way ANOVA followed by Bonferroni/Dunn multiple comparison test or Student's $t$-test.

\section{RESULTS}

\section{Binding Properties of Oxycodone with Opioid Receptor}

To evaluate the specific involvement of the opioid receptor types in oxycodone-induced pharmacological actions, we performed the competitive displacement-binding assay. At first, we determined the competitive displacement binding of the MOR ligand $\left[{ }^{3} \mathrm{H}\right] \mathrm{DAMGO}$ (Figure 1a), the $\delta$-opioid receptor (DOR) ligand $\left[{ }^{3} \mathrm{H}\right] \mathrm{DPDPE}$ (Figure $1 \mathrm{~b}$ ) or the KOR ligand $\left[{ }^{3} \mathrm{H}\right] \mathrm{U} 69,593$ (Figure 1c) with graded concentrations $\left(10^{-11}-10^{-7} \mathrm{M}\right)$ of unlabeled opioid agonists in membranes of the mouse brain without cerebellum (Figure 1a and b) and the guinea pig cerebellum, which is relatively rich in KOR sites (Figure 1c). As shown in Table $1, \mathrm{IC}_{50}$ values were determined by the displacement of $\left[{ }^{3} \mathrm{H}\right]$ DAMGO, $\left[{ }^{3} \mathrm{H}\right] D P D P E$, or $\left[{ }^{3} \mathrm{H}\right] \mathrm{U} 69,593$ (Table 1 ). The $\left[{ }^{3} \mathrm{H}\right]$ DAMGO binding was clearly displaced by morphine or oxycodone in a concentration-dependent manner. The affinity of oxycodone to the MOR binding was about 10 times lower than that of morphine. In contrast, the binding of either $\left[{ }^{3} \mathrm{H}\right]$ DPDPE or $\left[{ }^{3} \mathrm{H}\right] \mathrm{U} 69,593$ was not affected by morphine or oxycodone, whereas $\left[{ }^{3} \mathrm{H}\right] \mathrm{DPDPE}$ or $\left[{ }^{3} \mathrm{H}\right] \mathrm{U} 69,593$ binding was displaced by increasing concentrations of either a selective DOR agonist SNC80 or a specific KOR agonist U50,488, respectively.
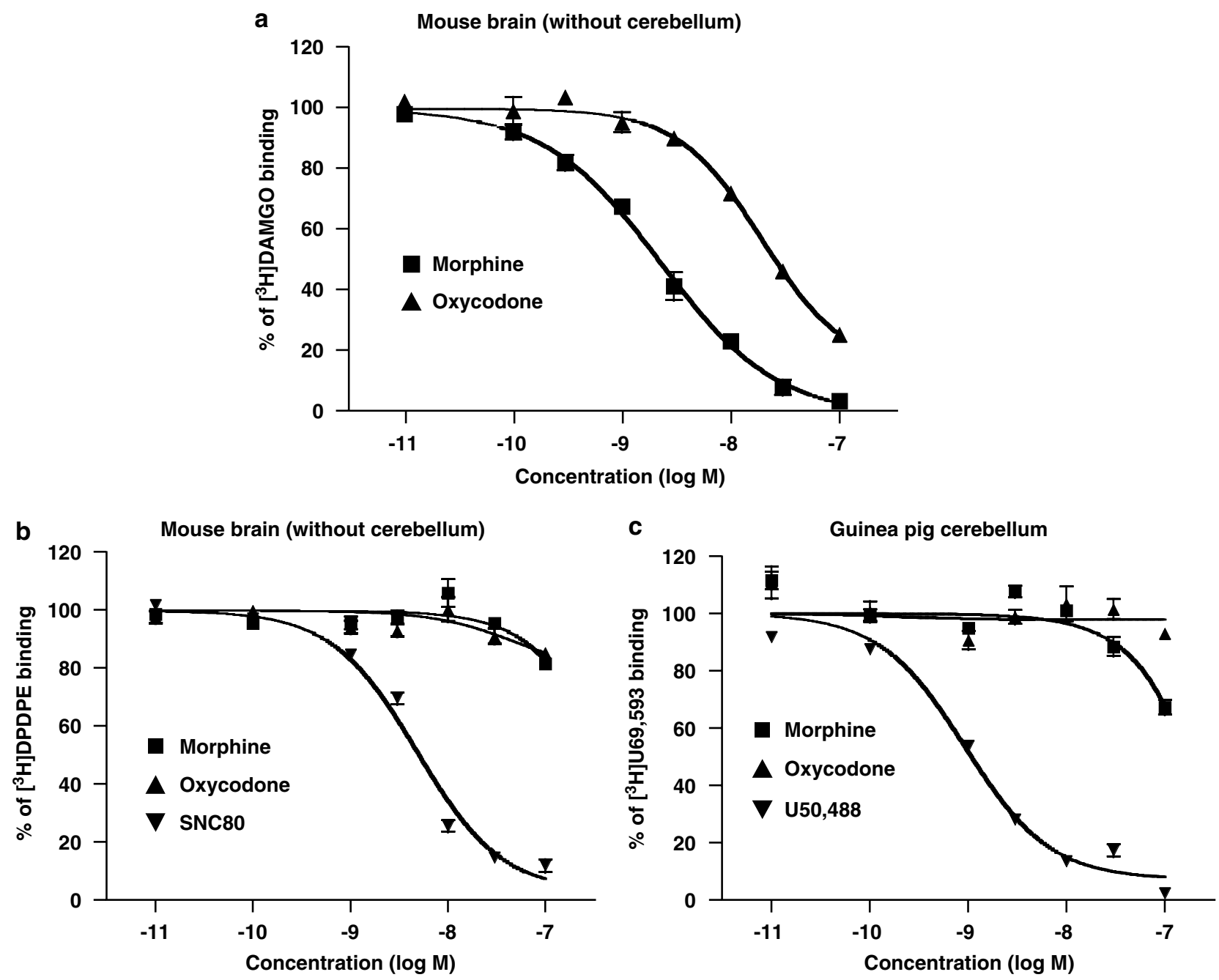

Figure I Displacement of the MOR ligand $\left[{ }^{3} \mathrm{H}\right] \mathrm{DAMGO}$ (a), DOR ligand $\left[{ }^{3} \mathrm{H}\right] \mathrm{DPDPE}(\mathrm{b})$, or the KOR ligand $\left[{ }^{3} \mathrm{H}\right] \mathrm{U} 69,593$ (c) binding in membranes of the mouse brain without cerebellum (a or b) and the guinea pig cerebellum (c) by morphine, oxycodone, SNC80, or U50,488. Experiments were performed in the presence of either [ $\left.{ }^{3} \mathrm{H}\right] \mathrm{DAMGO}(\mathrm{I} \mathrm{nM}),\left[{ }^{3} \mathrm{H}\right] \mathrm{DPDPE}(2 \mathrm{nM})$, or $\left.{ }^{3} \mathrm{H}\right] \mathrm{U} 69,593(2 \mathrm{nM})$ and increasing concentrations of morphine, oxycodone, SNC80, or $\cup 50,488$. The data represent the mean \pm SEM of three to four samples. 
Table I Binding Property of Oxycodone for the $\mu$-, $\delta$-, or $\kappa$-Opioid Receptor Determined by Displacement of $\left[{ }^{3} H\right] D A M G O,\left[{ }^{3} H\right] D P D P E$, or $\left[{ }^{3} \mathrm{H}\right] \cup 69,593$

\begin{tabular}{|c|c|c|c|c|c|}
\hline & Morphine & Oxycodone & Fentanyl & SNC80 & U50,488 \\
\hline$\left.{ }^{3} H\right] D P D P E(n M)$ & $<500$ & $<500$ & $<500$ & $5.17(3.90-6.84)$ & ND \\
\hline
\end{tabular}

$I_{50}$ values were determined using the analysis of variance and linear regression techniques. Groups were treated with morphine, oxycodone, fentanyl, SNC80, or U50,488. To calculate $I C_{50}$ values, at least seven drug doses were used and three to four samples were used for each dose. Values in parenthesis indicate the $95 \%$ confidence range.
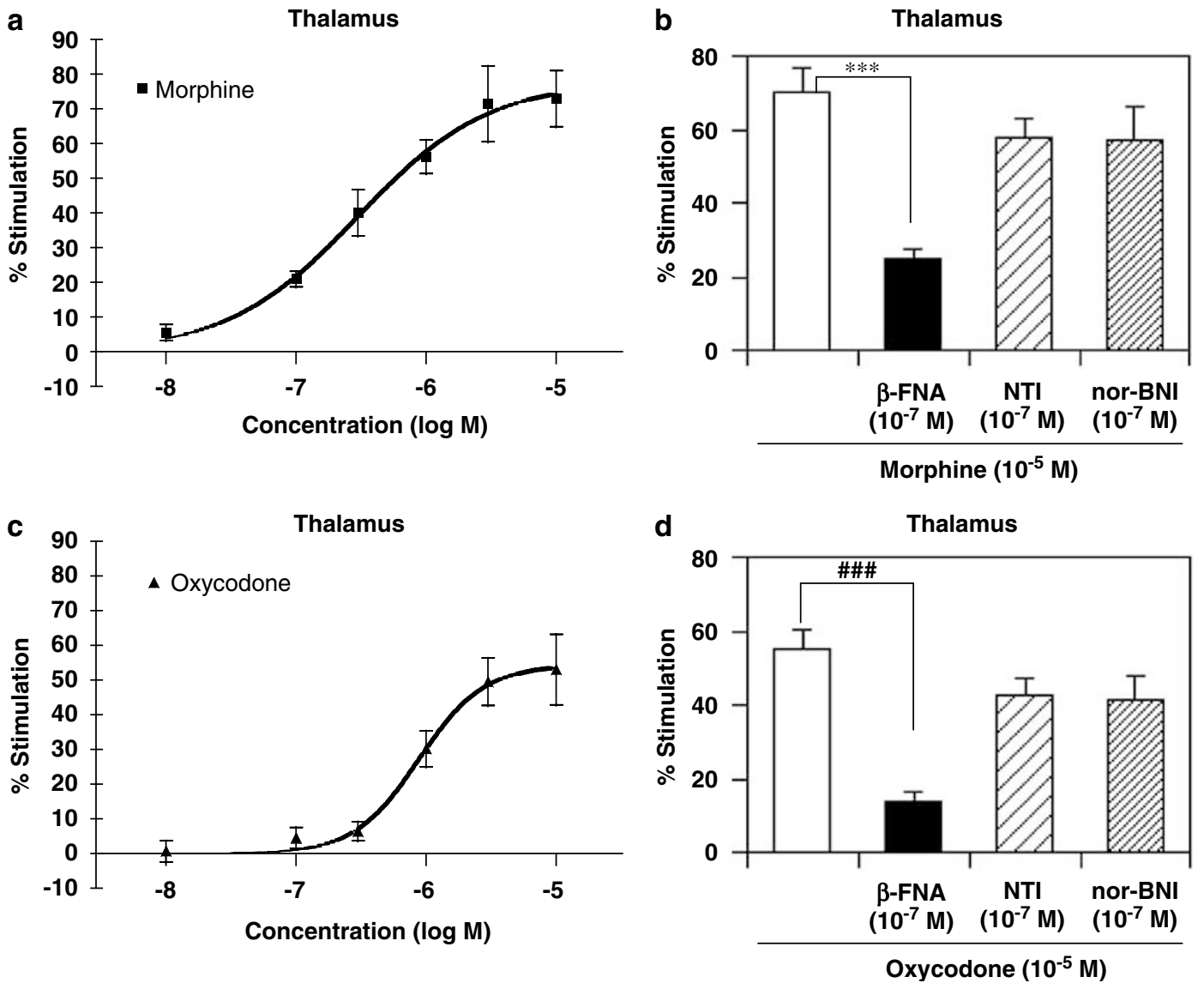

Figure 2 Concentration-response curve of $\left.{ }^{35} \mathrm{~S}\right] \mathrm{GTP} \gamma \mathrm{S}$ binding to membranes induced by morphine (a) or oxycodone (c) in the mouse thalamus. Either morphine- (b) or oxycodone (d)-induced increase in $\left.{ }^{35} \mathrm{~S}\right] \mathrm{GTP} \gamma \mathrm{S}$ binding to membranes of the mouse thalamus was blocked by the selective MOR antagonist $\beta$-FNA, but not the DOR antagonist NTI or the KOR antagonist nor-BNI. Membranes were incubated with $\left.{ }^{35} \mathrm{~S}\right] \mathrm{GTP} \gamma \mathrm{S}$ and GDP with morphine or oxycodone in the presence or absence of $\beta$-FNA, NTI or nor-BNI. The data are shown as the percentage of basal $\left[{ }^{35}\right.$ S] GTP $\gamma S$ binding measured in the presence of GDP and absence of morphine or oxycodone. Each column represents the mean \pm SEM of three to six samples. $* * * * 2<0.00$ I $\beta$-FNA-morphine vs morphine alone. ${ }^{\# \# \#} \mathrm{p}<0.00$ I $\beta$-FNA-oxycodone vs oxycodone alone.

We next investigated the ability of oxycodone to activate G-proteins in the mouse thalamus, spinal cord and the guinea pig cerebellum membranes. Either morphine $\left(10^{-8}\right.$ $\left.10^{-5} \mathrm{M}\right)$ or oxycodone $\left(10^{-8}-10^{-5} \mathrm{M}\right)$ showed a concentration-dependent increase in the binding of $\left[{ }^{35} \mathrm{~S}\right] \mathrm{GTP} \gamma \mathrm{S}$ to membranes of the mouse thalamus (Figure 2a and c) and spinal cord (Figure 3a and c). Co-incubation with a MOR antagonist $\beta$-FNA $\left(10^{-7} \mathrm{M}\right)$ significantly attenuated either morphine- or oxycodone-induced G-protein activation, whereas either a DOR antagonist NTI $\left(10^{-7} \mathrm{M}\right)$ or a KOR antagonist nor-BNI $\left(10^{-7} \mathrm{M}\right)$ failed to affect those of morphine and oxycodone $(* * * p<0.001 \quad \beta$-FNA-morphine vs morphine alone, \#\# $p<0.001 \quad \beta$-FNA-oxycodone $v s$ oxycodone alone, Figures $2 \mathrm{~b}$ and $\mathrm{d}, 3 \mathrm{~b}$ and d). Conventional KOR agonists, U50,488 and ICI-199,441 $\left(10^{-8}-10^{-5} \mathrm{M}\right)$ produced a concentration-dependent increase in $\left[{ }^{35} \mathrm{~S}\right] \mathrm{GTP} \gamma \mathrm{S}$ binding to membranes of the guinea pig cerebellum region (Figure 4). In contrast, morphine $\left(10^{-8}-10^{-5} \mathrm{M}\right)$ showed relatively smaller increase in the binding of $\left[{ }^{35} \mathrm{~S}\right] \mathrm{GTP} \gamma \mathrm{S}$ than that of KOR agonists. Further- 

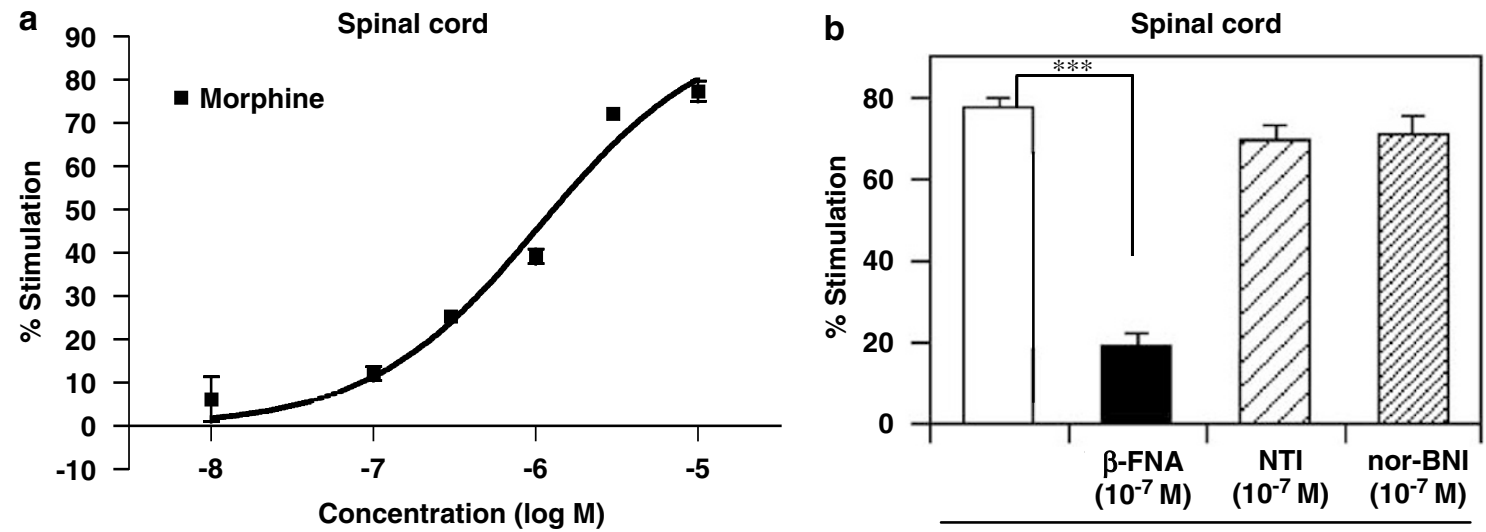

Morphine $\left(10^{-5} \mathrm{M}\right)$

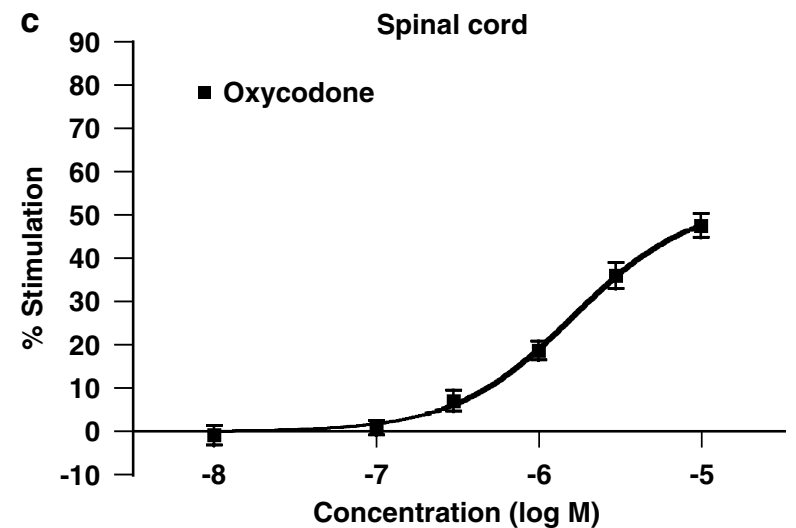

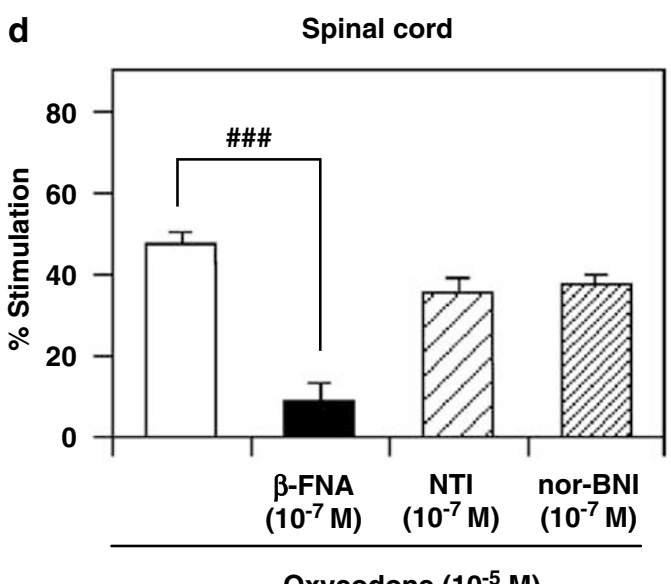

Figure 3 Concentration-response curve of $\left.{ }^{35} \mathrm{~S}\right] \mathrm{GTP} \gamma \mathrm{S}$ binding to membranes induced by morphine (a) or oxycodone (c) in the mouse spinal cord. Either morphine- (b) or oxycodone (d)-induced increase in $\left.{ }^{35} \mathrm{~S}\right] \mathrm{GTP} \gamma \mathrm{S}$ binding to membranes of the mouse spinal cord was blocked by the selective MOR antagonist $\beta$-FNA, but not the DOR antagonist NTI or the KOR antagonist nor-BNI. Membranes were incubated with $\left[^{35} \mathrm{~S}\right] \mathrm{GTP} \gamma \mathrm{S}$ and GDP with morphine or oxycodone in the presence or absence of $\beta$-FNA, NTI, or nor-BNI. The data are shown as the percentage of basal [ $\left.{ }^{35} \mathrm{~S}\right] \mathrm{GTP} \gamma \mathrm{S}$ binding measured in the presence of GDP and absence of morphine or oxycodone. Each column represents the mean \pm SEM of four to six samples. $* * * p<0.00$ I $\beta$-FNA-morphine vs morphine alone. ${ }^{\# \#} p<0.001 \quad \beta$-FNA-oxycodone vs oxycodone alone.

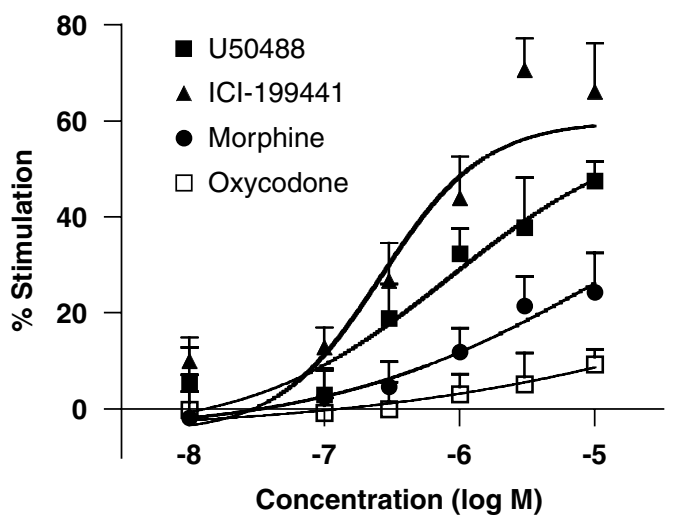

Figure 4 Concentration-response curve of $\left[{ }^{35} \mathrm{~S}\right] \mathrm{GTP} \gamma \mathrm{S}$ binding to membranes obtained from the guinea pig cerebellum by $\mathrm{U} 50,488, \mathrm{ICl}-$ 199,441, oxycodone, or morphine. The columns are expressed as the percentage of basal $\left[{ }^{35} \mathrm{~S}\right] \mathrm{GTP} \gamma \mathrm{S}$ binding. The data represent the mean \pm SEM of four samples.

more, a little change in the binding of $\left[{ }^{35} \mathrm{~S}\right] \mathrm{GTP} \gamma \mathrm{S}$ to membranes of the guinea pig cerebellum region was noted by oxycodone $\left(10^{-8}-10^{-5} \mathrm{M}\right)$ (Figure 4$)$.
We next investigated the role of MOR in oxycodone $(3 \mathrm{mg} / \mathrm{kg}$, s.c.)-induced antinociception using the tail-flick assay. Pretreatment with $\beta$-FNA ( $40 \mathrm{mg} / \mathrm{kg}$, s.c.) significantly attenuated the oxycodone-induced antinociception (Figure $5 \mathrm{a}, \quad{ }^{*} p<0.05, \quad{ }^{* *} p<0.001$ vs saline-pretreated group), whereas either nor-BNI $(5 \mathrm{mg} / \mathrm{kg}$, s.c.) or NTI $(3 \mathrm{mg} / \mathrm{kg}$, s.c.) had no effect on the antinociception of oxycodone (Figure $5 \mathrm{~b}$ and $\mathrm{c}$ ).

\section{Effect of s.c. Injection of Morphine or Oxycodone on} Thermal Hyperalgesia Induced by Sciatic Nerve Ligation or Intraplantar Injection of CFA in Mice

Sciatic nerve-ligated mice produce the state of neuropathic pain-like hypersensitivity. The persistent painful state caused by sciatic nerve ligation lasted for more than 21 days (data not shown). In the present study, mice with partial sciatic nerve ligation exhibited marked neuropathic pain-like behavior only ipsilateral side at 7 days after the nerve ligation $\quad{ }^{* *} p<0.01, \quad{ }^{* *} p<0.001$ vs sham-saline group) (Figure 6a and b). Unilateral intraplantar injection of CFA into the mouse hind paw produces the state of inflammatory pain-like hypersensitivity, which caused a 

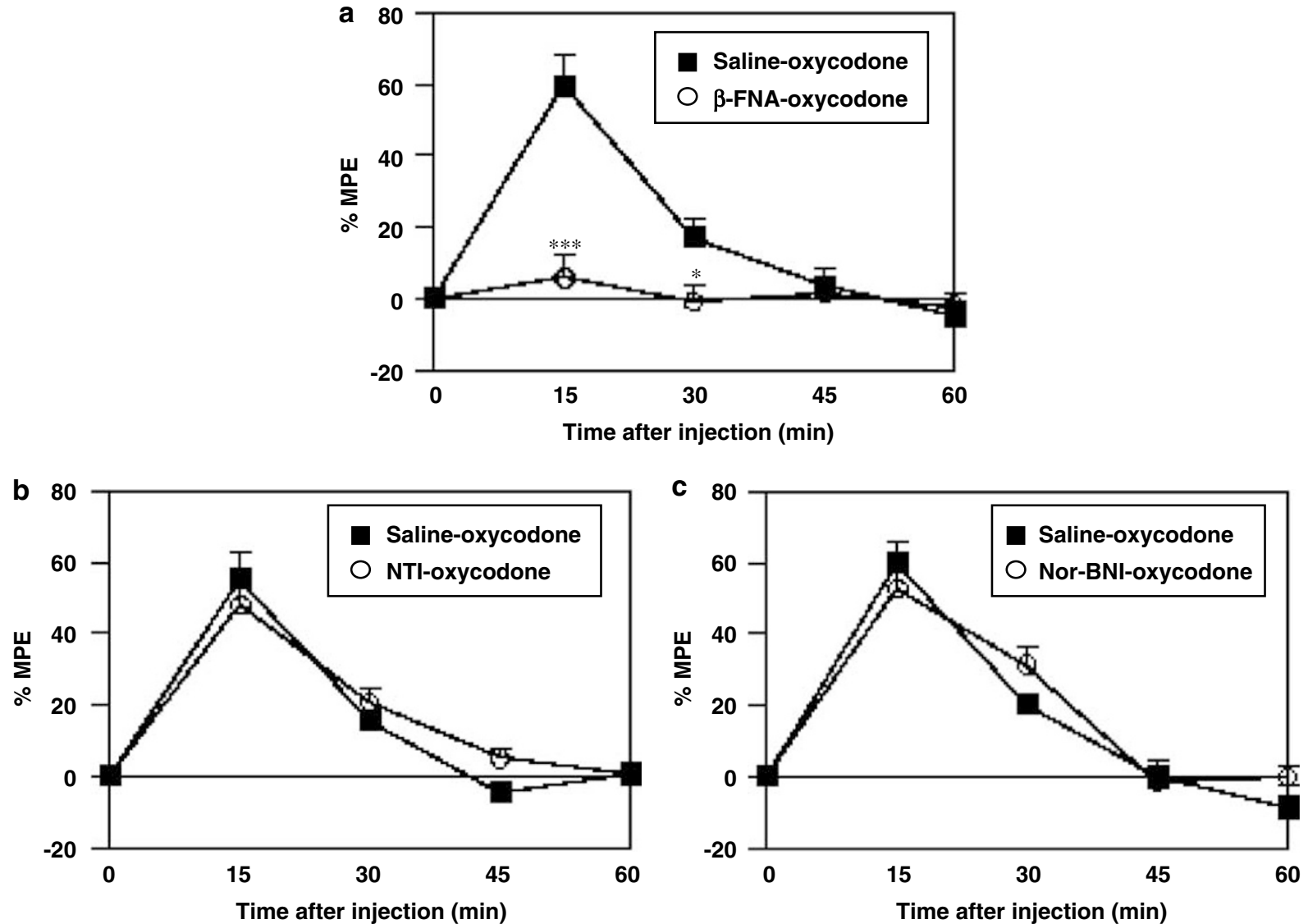

Figure 5 Effects of pretreatment with MOR antagonist $\beta$-FNA (a), DOR antagonist NTI (b), or KOR antagonist nor-BNI (c) on s.c. oxycodone-induced antinociception in mice. Antinociception was expressed as a \% MPE. Groups of mice were pretreated with $\beta$-FNA $(40 \mathrm{mg} / \mathrm{kg}), \mathrm{NTI}(3 \mathrm{mg} / \mathrm{kg})$, or nor-BNI $(5 \mathrm{mg} / \mathrm{kg})$ at $24 \mathrm{~h}, 30 \mathrm{~min}$, or $24 \mathrm{~h}$, respectively, before s.c. administration of oxycodone $(1.7 \mathrm{mg} / \mathrm{kg})$. Each point represents the mean \pm SEM of $6-10 \mathrm{mice}$. * $p<0.05$ and $* * * * 0.00$ I vs saline +oxycodone.

marked decrease in the latency of paw withdrawal against a thermal stimulus only on the ipsilateral side in mice $\left({ }^{* *} p<0.001\right.$ vs saline-saline group) (Figure $6 c$ and $\mathrm{d}$ ). The persistent painful state caused by intraplantar injection of CFA lasted for more than 14 days following CFA treatment in mice (data not shown). The s.c. injection of either morphine $(1-10 \mathrm{mg} / \mathrm{kg})$ or oxycodone $(0.1-3 \mathrm{mg} / \mathrm{kg})$ 7 days after sciatic nerve ligation or 1 day after CFA treatment recovered the decreased thermal threshold observed on the ipsilateral side in sciatic nerve-ligated or CFA-treated mice in a dose-dependent manner, and maximal anti-hyperalgesic responses were seen at 30 or $15 \mathrm{~min}$ after morphine or oxycodone injection, respectively (ligation-morphine $1 \mathrm{mg} / \mathrm{kg},{ }^{* *} p<0.001$; ligation-morphine $3 \mathrm{mg} / \mathrm{kg},{ }^{* *} p<0.01$ vs sham-saline group: Figure 6 a, ligationoxycodone 0.1 or $1 \mathrm{mg} / \mathrm{kg},{ }^{* *} p<0.01$; ligation-oxycodone $3 \mathrm{mg} / \mathrm{kg}, \quad{ }^{* *} p<0.001$ vs sham-saline group: Figure $6 \mathrm{~b}$, CFA-morphine 1,5 , or $10 \mathrm{mg} / \mathrm{kg},{ }^{* *} p<0.001$ vs salinesaline group: Figure $6 c$, CFA-oxycodone 0.1 or $3 \mathrm{mg} / \mathrm{kg}$, ${ }^{* * *} p<0.001$; CFA-oxycodone $1 \mathrm{mg} / \mathrm{kg},{ }^{* *} p<0.01$ vs salinesaline group: Figure $6 \mathrm{~d}$ ). At the dose of $5 \mathrm{mg} / \mathrm{kg}$ or $0.5 \mathrm{mg} /$ $\mathrm{kg}$, s.c. administration of morphine or oxycodone, respectively, almost completely reversed the decrease in the thermal threshold without excessive effects in sciatic nerveligated mice. In contrast, either $3 \mathrm{mg} / \mathrm{kg}$ (s.c.) of morphine or $0.5 \mathrm{mg} / \mathrm{kg}$ (s.c.) of oxycodone reversed the decreased thermal threshold in CFA-treated mice.

\section{Characterization of the Antinociception Induced by Morphine or Oxycodone under a Neuropathic-Pain like State}

We evaluated the antinociceptive effects induced by s.c. administration of morphine or oxycodone in shamoperated and sciatic nerve-ligated mice using the tail-flick assay. In the present study, s.c. administration of either morphine or oxycodone produced a dose-dependent antinociceptive effect in sham-operated mice, and maximal antinociceptive responses were seen at 30 and $15 \mathrm{~min}$ after injection, respectively. The antinociceptive effect of s.c.-injected morphine was significantly decreased in sciatic nerve-ligated mice (ligation-morphine $1.7 \mathrm{mg} / \mathrm{kg}$, ${ }^{\star} p<0.05$; ligation-morphine 3 or $5.6 \mathrm{mg} / \mathrm{kg},{ }^{* *} p<0.01$; ligationmorphine $10 \mathrm{mg} / \mathrm{kg},{ }^{* *} p<0.001$ vs sham-morphine group) (Figure 7a). In contrast, s.c. injection of oxycodone produced profound antinociception in sciatic nerve-ligated mice at the same level as observed in sham-operated mice (Figure 7b).

We next examined the antinociceptive effects induced by either i.t.- or i.c.v.-administered morphine or oxycodone in 

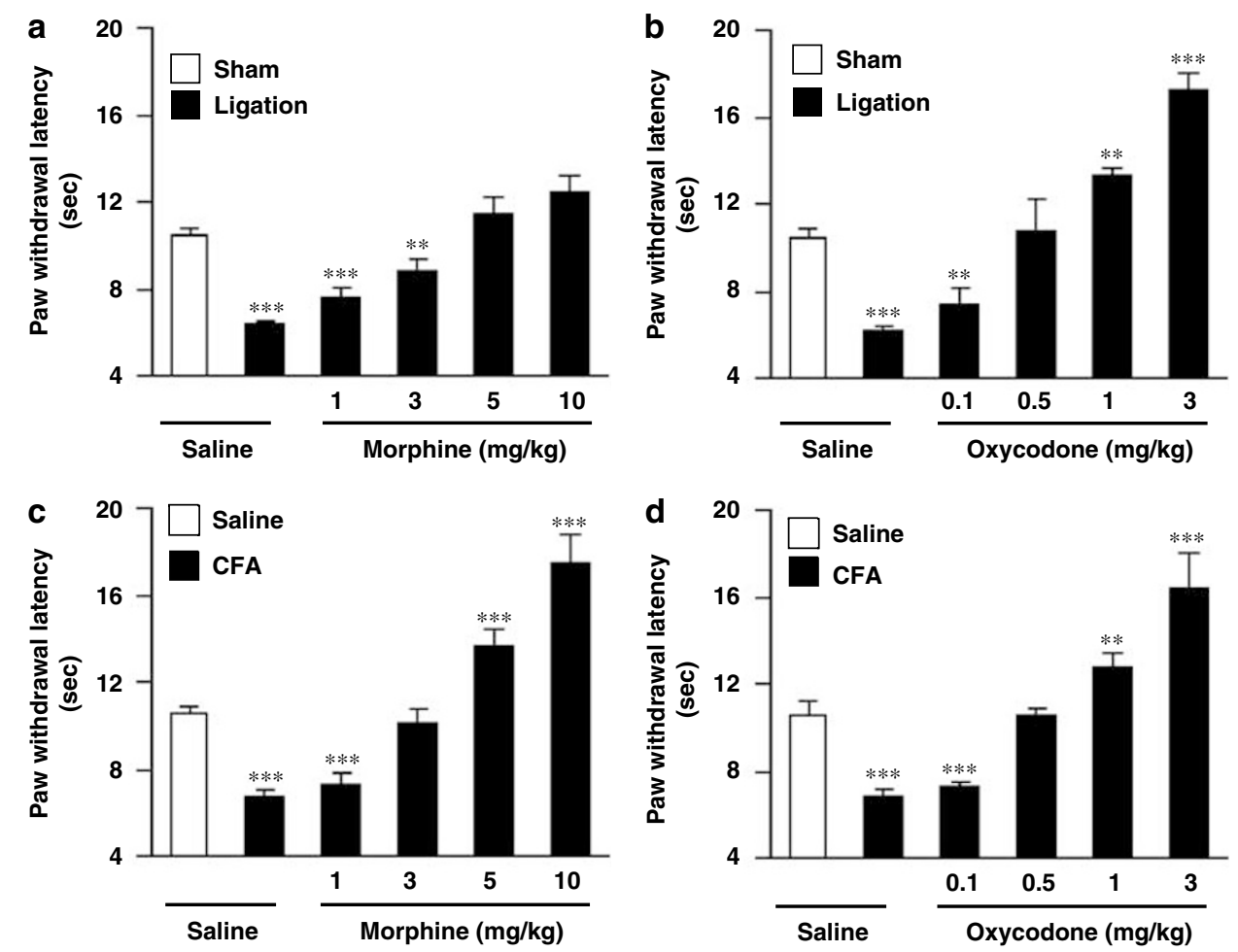

Figure 6 Effect of s.c. injection of morphine (a or c) or oxycodone (b or d) on the latency of paw withdrawal in response to thermal stimulus on the ipsilateral side in sham-operated and sciatic nerve-ligated mice (a or b) or saline- or CFA-injected mice (c or d). Measurement of thermal threshold was performed just before and 30 or 15 min after s.c. injection of morphine or oxycodone, respectively. Groups of mice were treated with morphine (I-10 mg/ $\mathrm{kg}$ ) or oxycodone $(0.1-3 \mathrm{mg} / \mathrm{kg}) 7$ days after sciatic nerve ligation or I day after CFA injection. Each column represents the mean \pm SEM of 6-II mice. **** $p<0.001$ and $* * * 0.01$ vs sham-saline group or saline-saline group.

sham-operated and sciatic nerve-ligated mice. I.t. injected morphine or oxycodone each had a dose-dependent antinociceptive effect in sham-operated and sciatic nerveligated mice (Figure $7 \mathrm{c}$ and $\mathrm{d}$ ). The maximal antinociceptive effect of i.t.-administered morphine or oxycodone was observed at 10 or $5 \mathrm{~min}$, respectively, following each injection (data not shown). I.c.v.-administered morphine and oxycodone each produced significant antinociception in sciatic nerve-ligated mice to the same level as observed in sham-operated mice (Figure $7 \mathrm{e}$ and $\mathrm{f}$ ). The maximal antinociceptive effect of i.c.v.-administered morphine or oxycodone was observed 10 or $5 \mathrm{~min}$, respectively, following each injection (data not shown). As shown in Table 2, the $\mathrm{ED}_{50}$ values for the antinociceptive effects of morphine and oxycodone following each injection in sham-operated or sciatic nerve-ligated mice (Table 2).

\section{Spinal and Supraspinal G-Protein Activation Induced by} Morphine or Oxycodone in Nerve-Ligated Mice

We next investigated the ability of morphine (Figure 8a, $\mathrm{c}$ and e) or oxycodone (Figure $8 \mathrm{~b}, \mathrm{~d}$ and $\mathrm{f}$ ) to activate $\mathrm{G}$ proteins through the stimulation of MORs in membranes of the mouse spinal cord (Figure 8a and b), PAG (Figure 8c and $\mathrm{d}$ ), and thalamus (Figure $8 \mathrm{e}$ and $\mathrm{f}$ ) obtained from shamoperated and sciatic nerve-ligated mice. The activation of $\mathrm{G}$ proteins induced by morphine or oxycodone $\left(10^{-8}-10^{-5} \mathrm{M}\right)$ in these areas was examined by monitoring the binding of $\left[{ }^{35} \mathrm{~S}\right] \mathrm{GTP} \gamma \mathrm{S}$ to membranes. Morphine and oxycodone each produced a concentration-dependent increase in $\left[{ }^{35} \mathrm{~S}\right] \mathrm{GTP} \gamma \mathrm{S}$ binding to membranes of the mouse spinal cord, PAG and thalamus in sham-operated mice (Figure 8). In sciatic nerve-ligated mice, the levels of $\left[{ }^{35} \mathrm{~S}\right] \mathrm{GTP} \gamma \mathrm{S}$ binding stimulated by morphine and oxycodone were similar to that found in sham-operated mice (Figure 8).

Suppression of the Antinociceptive Effect and G-Protein Activation Induced by M-6-G at Spinal or Supraspinal Levels under a Neuropathic Pain-like State

In the mouse tail-flick test, either s.c.-, i.t.- or i.c.v. administration of M-6-G induced marked antinociception in sham-operated mice as with morphine and oxycodone (Figure 9). The antinociceptive effects induced by all three injections of $M-6-G$ were significantly decreased in nerveligated mice compared with those in sham-operated mice (s.c.: ligation-M-6-G 1 or $5.6 \mathrm{mg} / \mathrm{kg}{ }^{\star} p<0.05 ; 1.7$ or $3 \mathrm{mg} / \mathrm{kg}$ ${ }_{* * *} p<0.001$ vs sham-M-6-G group; i.t.: ligation-M-6-G 0.01 or $0.03 \mathrm{nmol} /$ mouse ${ }^{* * *} p<0.001 ; 0.056$ or $0.1 \mathrm{nmol} /$ mouse ${ }^{* *} p<0.01$ vs sham-M-6-G group; i.c.v.: ligation-M-6-G $0.03 \mathrm{nmol} /$ mouse ${ }^{\star} p<0.01 ; \quad 0.3$ or $0.56 \mathrm{nmol} / \mathrm{mouse}$ ${ }_{* * *} p<0.001$ vs sham-M-6-G group) (Figure 9a-c).

We further investigated the changes in the ability of M-6-G to activate G-proteins in membranes of the spinal cord, PAG or thalamus obtained from sham-operated or sciatic nerve-ligated mice. The binding of $\left[{ }^{35} \mathrm{~S}\right] \mathrm{GTP} \gamma \mathrm{S}$ stimulated by $M-6-G$ was significantly decreased in nerve-ligated mice, whereas $\mathrm{M}-6-\mathrm{G}\left(10^{-8}-10^{-5} \mathrm{M}\right)$ produced a concentration- 

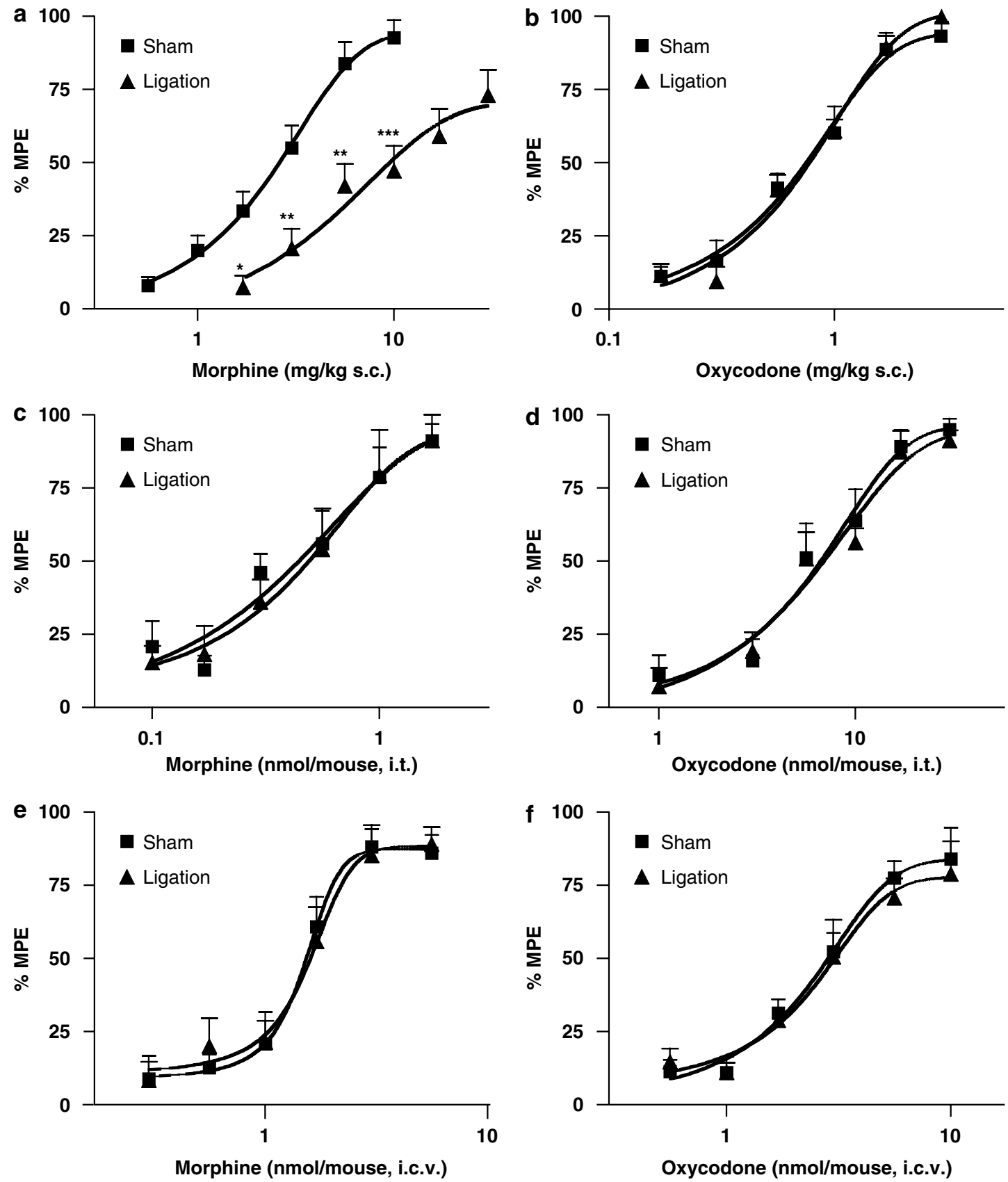

Figure 7 Dose-response curves for the antinociceptive effect induced by s.c., i.t., or i.c.v. morphine (a, c, or e) or oxycodone (b, d, or $\mathrm{f}$ ) in sham-operated and sciatic nerve-ligated mice. Groups of mice were treated with morphine $(0.56-30 \mathrm{mg} / \mathrm{kg}$, s.c., $0.1-1.7 \mathrm{nmol} / \mathrm{mouse}$, i.t., or $0.3-5.6 \mathrm{nmol} / \mathrm{mouse}$, i.c.v.) or oxycodone $(0.17-3 \mathrm{mg} / \mathrm{kg}$, s.c., $1-30 \mathrm{nmol} /$ mouse, i.t., or $0.56-10 \mathrm{nmol} / \mathrm{mouse}$, i.c.v.) 7 days after nerve ligation. Antinociceptive effects were measured at 30 or $15 \mathrm{~min}$ after s.c., 10 or $5 \mathrm{~min}$ after i.t. or 10 or $5 \mathrm{~min}$ after i.c.v. injection of morphine or oxycodone as the peak time of morphine or oxycodone activity, respectively. Antinociception was expressed as a \% MPE. Each value represents the mean \pm SEM of $8-10$ mice. $* p<0.05$, ** $p<0.01$, and $* * * p<0.001$ vs sham group.

dependent increase in the binding of $\left[{ }^{35} \mathrm{~S}\right] \mathrm{GTP} \gamma \mathrm{S}$ to membranes of the spinal cord and PAG area in shamoperated mice (spinal cord: $\mathrm{F}_{(1,42)}=28.80,{ }^{* *} p<0.01 v s$ ligation-M-6-G group; PAG: $\mathrm{F}_{(1,36)}=13.36,{ }^{* *} p<0.01 v s$ ligation-M-6-G group) (Figure 10a and $\mathrm{b}$ ). On the other hand, M-6-G produced a concentration-dependent increase in $\left[{ }^{35} \mathrm{~S}\right] \mathrm{GTP} \gamma \mathrm{S}$ binding to membranes of the mouse thalamus in sham-operated mice. In sciatic nerve-ligated mice, the level of $\left[{ }^{35}\right.$ S $]$ GTP $\gamma$ S binding stimulated by M-6-G in the thalamus was similar to that found in sham-operated mice (Figure 10c).

Inhibition of Morphine- or Oxycodone-Induced Place Preference and G-Protein Activation in the Lower Midbrain with Sciatic Nerve-Ligated Mice

We next investigated whether morphine or oxycodone could produce rewarding effects in sciatic nerve-ligated 
mice using the CPP method. As shown in Figure 11, s.c.-administered morphine and oxycodone each produced a dose-dependent preference for the drug-associated place in sham-operated mice (sham-morphine 3 or $5.6 \mathrm{mg} / \mathrm{kg}$, shamoxycodone 1 or $3 \mathrm{mg} / \mathrm{kg},{ }^{\# \#} p<0.01$; sham-morphine $10 \mathrm{mg} /$ $\mathrm{kg}{ }^{\# \# \#} p<0.001$ vs sham-saline group). In contrast, neither morphine nor oxycodone induced a place preference under a neuropathic pain-like state (ligation-morphine 5.6 or $10 \mathrm{mg} / \mathrm{kg}{ }^{\star} p<0.05$; ligation-oxycodone 1 or $3 \mathrm{mg} / \mathrm{kg}$ ${ }^{*} p<0.05$ vs sham-morphine or -oxycodone group) (Figure $11 \mathrm{a}$ and $\mathrm{b}$ ).

We assessed the morphine- or oxycodone-induced increase in $\left[{ }^{35} \mathrm{~S}\right] \mathrm{GTP} \gamma \mathrm{S}$ binding in the lower midbrain including the VTA obtained from sham-operated or sciatic nerve-ligated mice. According to atlas described by Paxions and Franklin (2001), the coronal brain block of the lower midbrain area (box) was dissected obtained from 2.5 to $4.5 \mathrm{~mm}$ posterior to bregma (Figure 11c). Morphine and oxycodone $\left(10^{-8}-10^{-5} \mathrm{M}\right)$ each produced a concentrationdependent increase in the binding of $\left[{ }^{35} \mathrm{~S}\right] \mathrm{GTP} \gamma \mathrm{S}$ to lower midbrain membranes in sham-operated mice. Conversely, the level of $\left[{ }^{35} \mathrm{~S}\right] \mathrm{GTP} \gamma \mathrm{S}$ binding to this area stimulated by morphine or oxycodone in nerve-ligated mice was significantly lower than that observed in sham-operated mice $\left(\mathrm{F}_{(1,36)}=13.43,{ }^{*} p<0.05\right.$ vs ligation-morphine group; $\mathrm{F}_{(1,36)}=20.36, \quad{ }^{\#} p<0.01$ vs ligation-oxycodone group) (Figure $11 \mathrm{~d}$ and $\mathrm{e}$ ).

\section{DISCUSSION}

The present binding studies clearly suggest that oxycodone possesses high affinity for MORs in the mouse brain. In contrast, oxycodone showed no affinity for DORs or KORs. In the $\left[{ }^{35} S\right]$ GTP $\gamma S$ binding, the increased level of $\left[{ }^{35} S\right]$ GTP $\gamma S$ binding to membranes of the mouse thalamus induced by oxycodone was abolished by the MOR antagonist $\beta$-FNA. Furthermore, oxycodone failed to affect $\left[{ }^{35} \mathrm{~S}\right] \mathrm{GTP} \gamma \mathrm{S}$ bindings to membranes of the guinea pig cerebellum, which is known to be a good source for the possible determination of KOR agonists. Consistent with these results, s.c. pretreatment with the $\beta$-FNA, but not NTI or nor-BNI, significantly attenuated the oxycodone-induced antinociception. Taken together, these findings suggest that the oxycodone-induced antinociception is mainly mediated through MORs in the CNS, and oxycodone can be classified as the preferential MOR agonist. However, our notion is inconsistent with the report by Ross and Smith (1997). In their report, the antinociception of oxycodone was antagonized by i.c.v. pretreatment of nor-BNI with a dose that failed to affect the antinociceptive effect induced by morphine, suggesting the implication of KOR in the oxycodone-induced antinociception. Although the specific reason for these discrepancies between previous studies by Ross and Smith and our studies remains unclear, one possibility is that the discrepancy may result from different experimental conditions. In the current study, we have carefully confirmed that neither KOR- nor DOR agonist-induced antinociceptive effect is attenuated by pretreatment with $\beta$-FNA at the present dose (data not shown). Additionally, it has been documented that oxycodone acts as the MOR agonist in mice and binds selectively to the MOR (Lemberg et al, 2006a). Thus, the present 


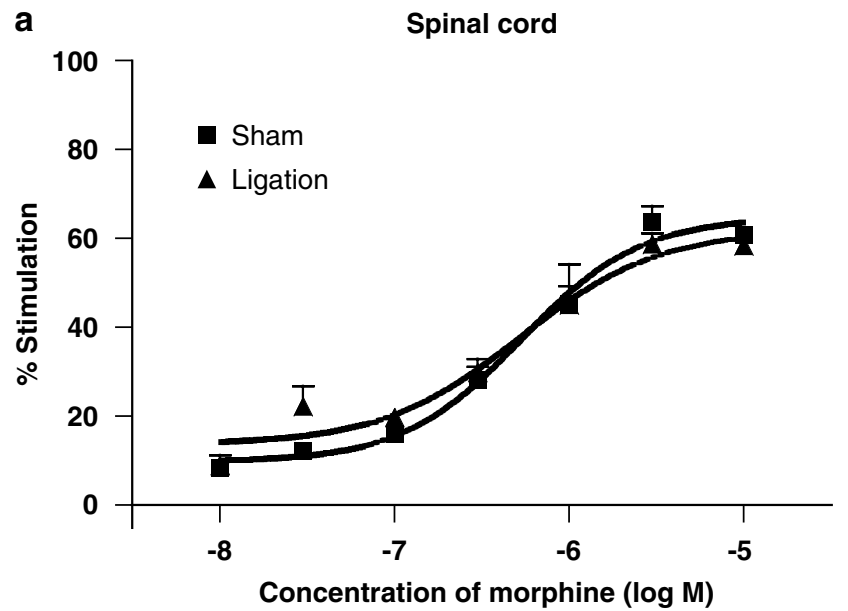

b Spinal cord
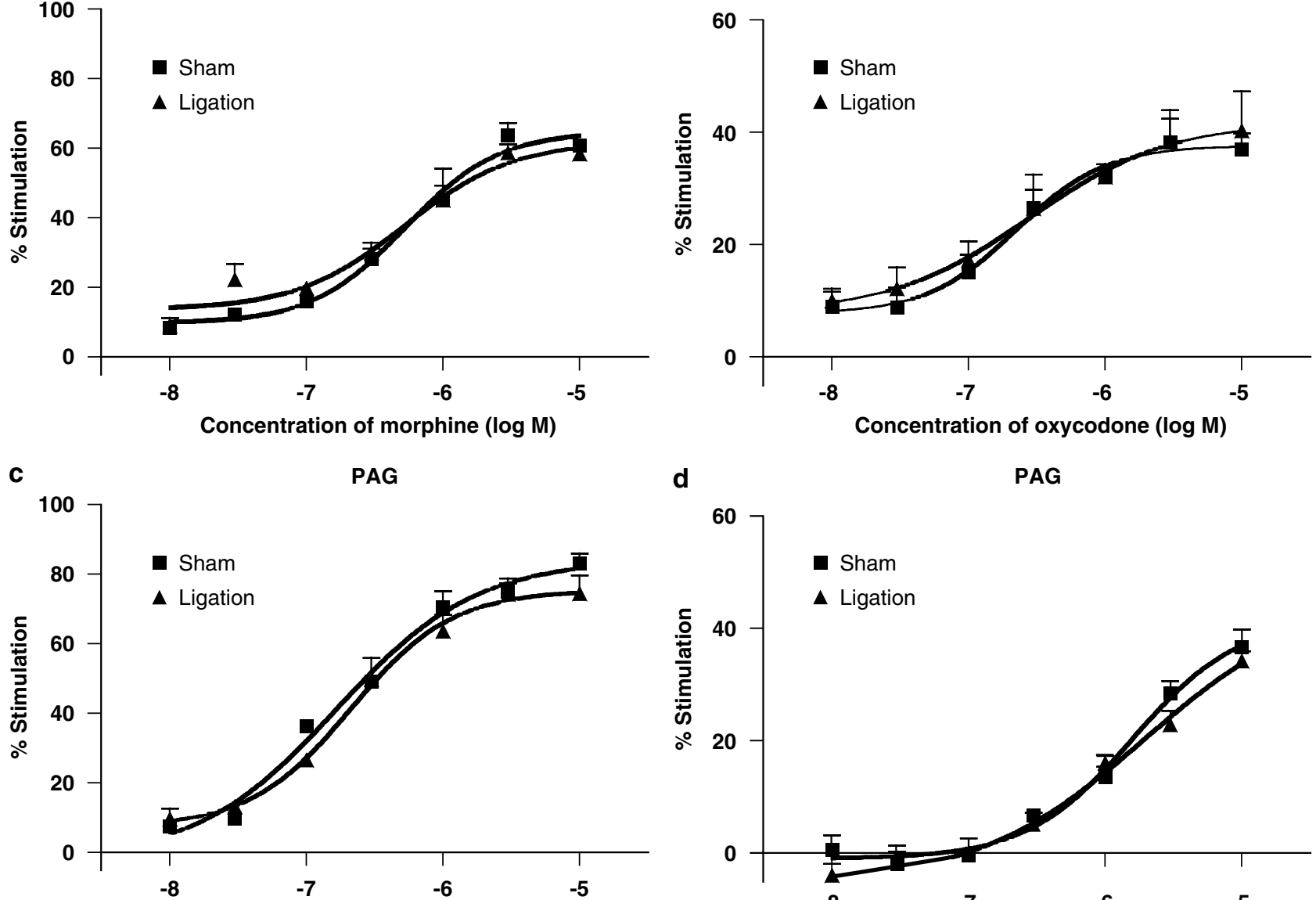

d

PAG
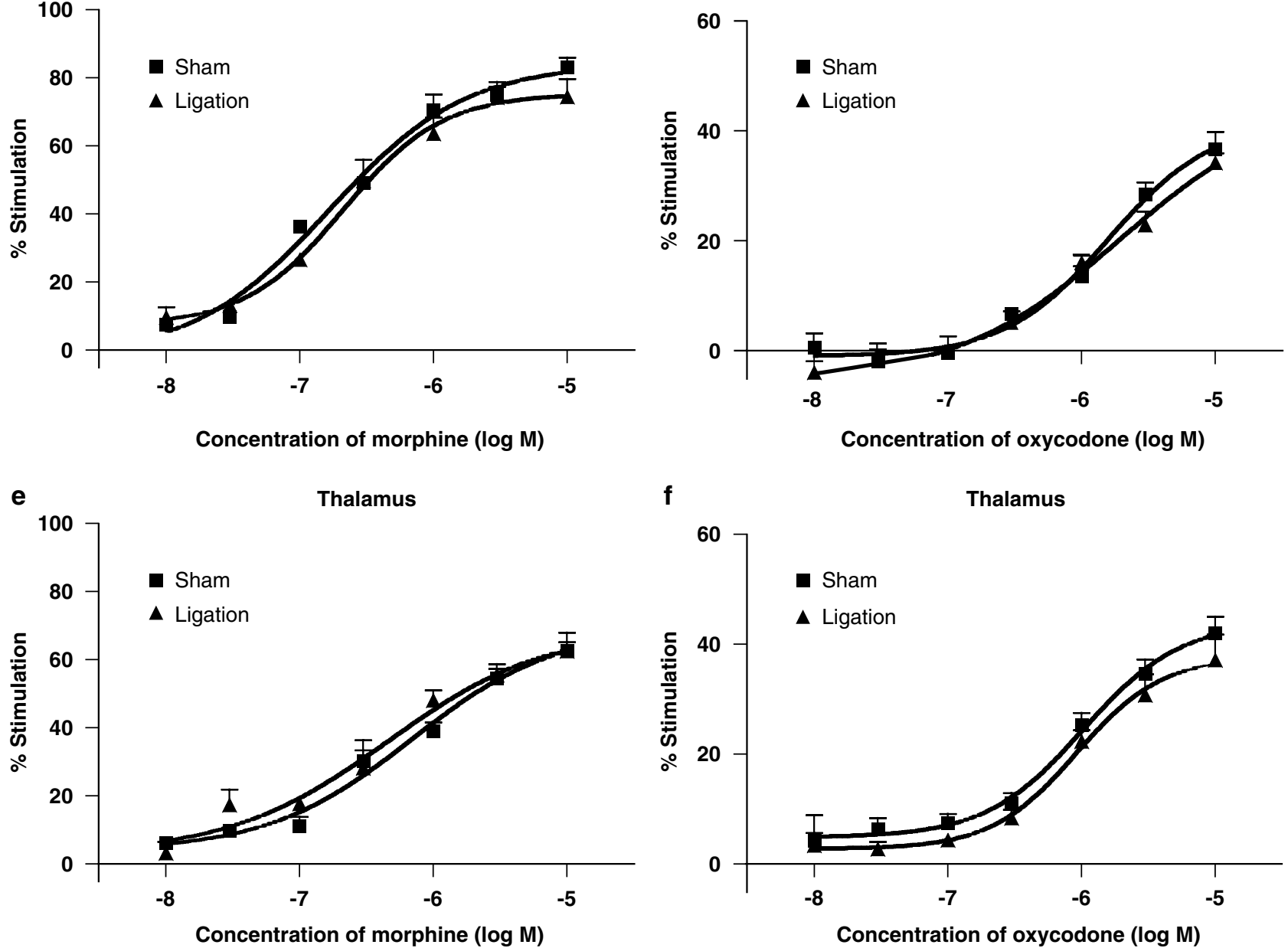

f

Thalamus

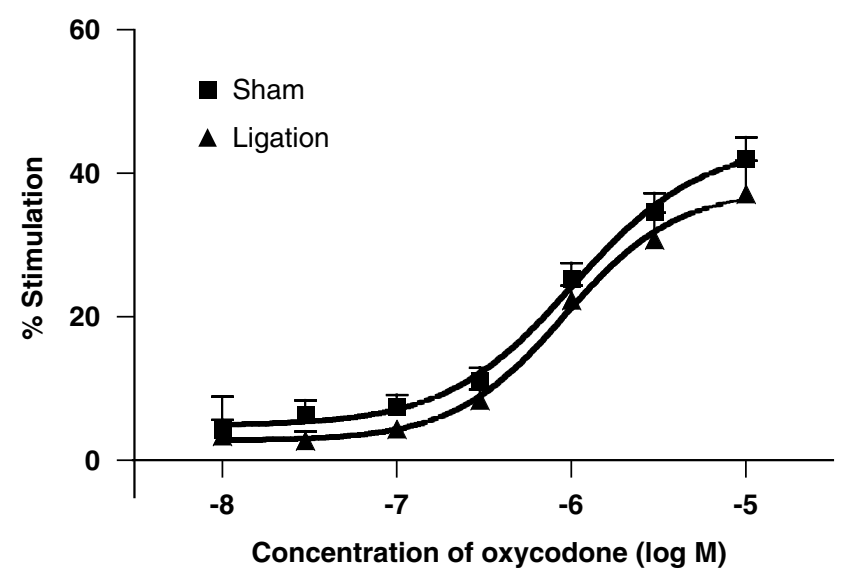

Figure 8 No difference was observed in the binding of $\left[{ }^{35} \mathrm{~S}\right] \mathrm{GTP} \gamma \mathrm{S}$ stimulated by morphine (a, c, or e) or oxycodone (b, d, or $\mathrm{f}$ ) in the spinal cord (a or $b$ ), the PAG (c or d) or thalamus (e or f) obtained from sham-operated and sciatic nerve-ligated mice. Membranes were prepared at 7 days after nerve ligation. Each value represents the mean \pm SEM of six samples.

findings further suggest that MOR, but not KOR, is the primary site for the expression of antinociception induced by oxycodone.

In the present study, we also found that oxycodone showed about 10 times lower ligand-binding affinity than that of morphine. On the other hand, morphine and oxycodone were equipotent antinociceptive agents. It has been recently reported that oxycodone shows lower efficacy and potency to stimulate $\left[{ }^{35} \mathrm{~S}\right] \mathrm{GTP} \gamma \mathrm{S}$ binding in the rat spinal cord and PAG than that of morphine or an oxycodone active metabolite, oxymorphone (Lemberg et al, 2006a). Although it is difficult to explain the reason 

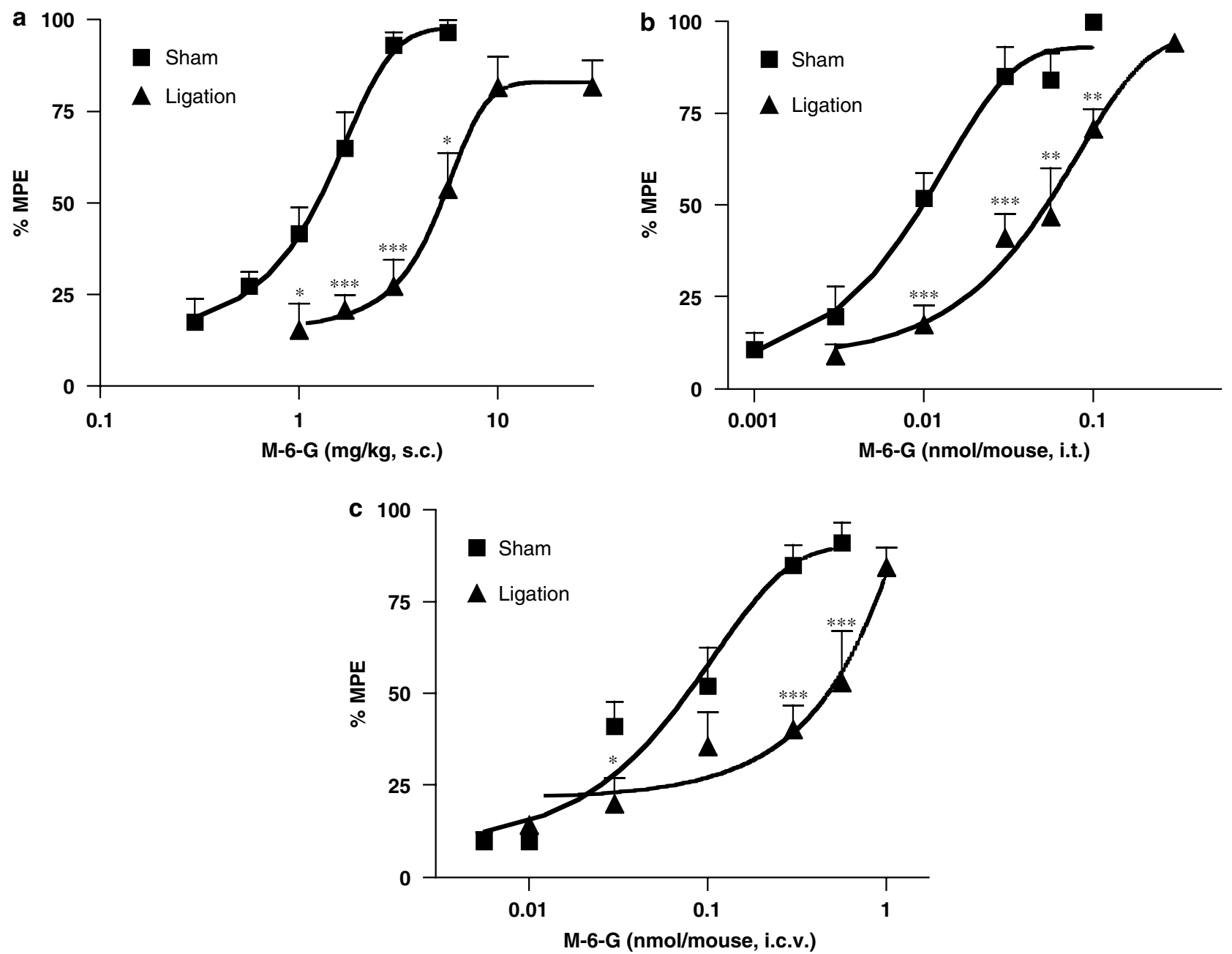

Figure 9 Dose-response curves for the antinociceptive effect induced by M-6-G in sham-operated and sciatic nerve-ligated mice. Groups of mice were treated s.c. $(0.3-30 \mathrm{mg} / \mathrm{kg}$, a), i.t.(0.00 I- $0.1 \mathrm{nmol} / \mathrm{mouse}, \mathrm{b})$, or i.c.v. $(0.0056-\mathrm{I} \mathrm{nmol} / \mathrm{mouse}$, c) with $\mathrm{M}-6-\mathrm{G} 7$ days after the nerve ligation. Antinociceptive effects were measured at 45, 10 , or 10 min after s.c., i.t., or i.c.v. injection of M-6-G as the peak time of M-6-G activity, respectively. Antinociception was expressed as a \% MPE. Each value represents the mean \pm SEM of $6-11$ mice. $* p<0.05$, $* * p<0.01$, **** $p<0.00$ I vs sham group.

for the lower affinity to the MOR for oxycodone than for morphine, current evidence demonstrated that oxycodone is actively influxed across the $\mathrm{BBB}$ rather than morphine (Tunblad et al, 2003; Bostrom et al, 2006), which could, at least in part, result from this phenomenon.

In the present study, a neuropathic pain-like state and an inflammatory pain-like state were suppressed by s.c. treatment with either morphine or oxycodone in a dosedependent manner. We proposed that the optimal doses for morphine- or oxycodone-induced anti-hyperalgesic effect in sciatic nerve-ligated and CFA-treated mice were $5 \mathrm{mg} / \mathrm{kg}$ or $0.5 \mu \mathrm{g} / \mathrm{kg}$ and 3 or $0.5 \mathrm{mg} / \mathrm{kg}$, respectively. The optimal dose for morphine under a neuropathic pain-like state showed higher than that under an inflammatory pain-like state. Unlike morphine, the optimal dose for oxycodone was equipotent between a neuropathic pain-like state and an inflammatory pain-like state. These results suggest that neuropathic pain can be relieved by high dose of morphine, while the treatment with oxycodone produces a profound anti-hyperalgesic effect with the same degree under both a neuropathic pain-like state and an inflammatory pain-like state.

Using tail-flick assay, we confirmed that the antinociceptive effect induced by s.c. injection of morphine was significantly decreased in sciatic nerve-ligated mice, whereas sciatic nerve ligation did not alter the effect of oxycodone. However, i.t.- and i.c.v. administration of morphine each produced a significant antinociceptive effect in sciatic nerve-ligated mice similar to that observed in sham-operated mice. Consistent with these results, the increase in $\left[{ }^{35} \mathrm{~S}\right] \mathrm{GTP} \gamma \mathrm{S}$ binding induced by morphine in membrane fractions of the spinal cord, PAG, and thalamus was not altered by sciatic nerve ligation. The present data are inconsistent with the previous findings that the effect of i.t.-administered morphine was attenuated under a neuropathic pain-like state in rodents (Siddall et al, 1994; Lee et al, 1995; Ossipov et al, 1995; Porreca et al, 1998). However, recent reports suggest the data that i.t. treatment with morphine produced greater dose-dependent inhibitions of neuronal nociception in rodents (Hao et al, 1998; 


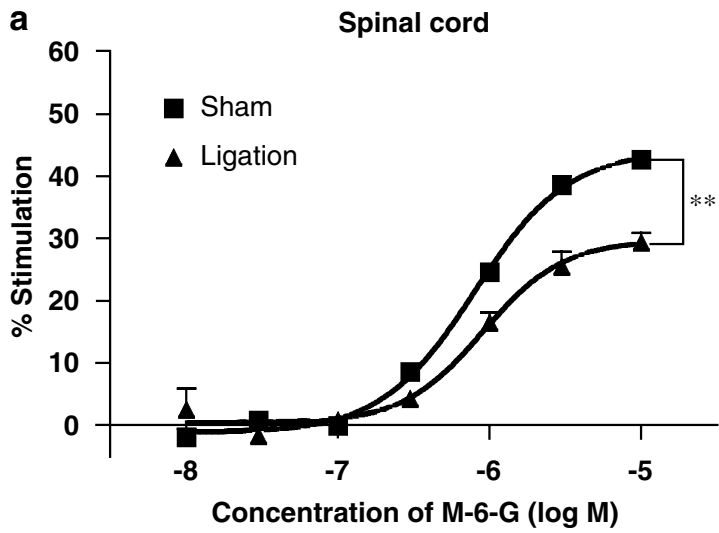

b $\quad$ PAG
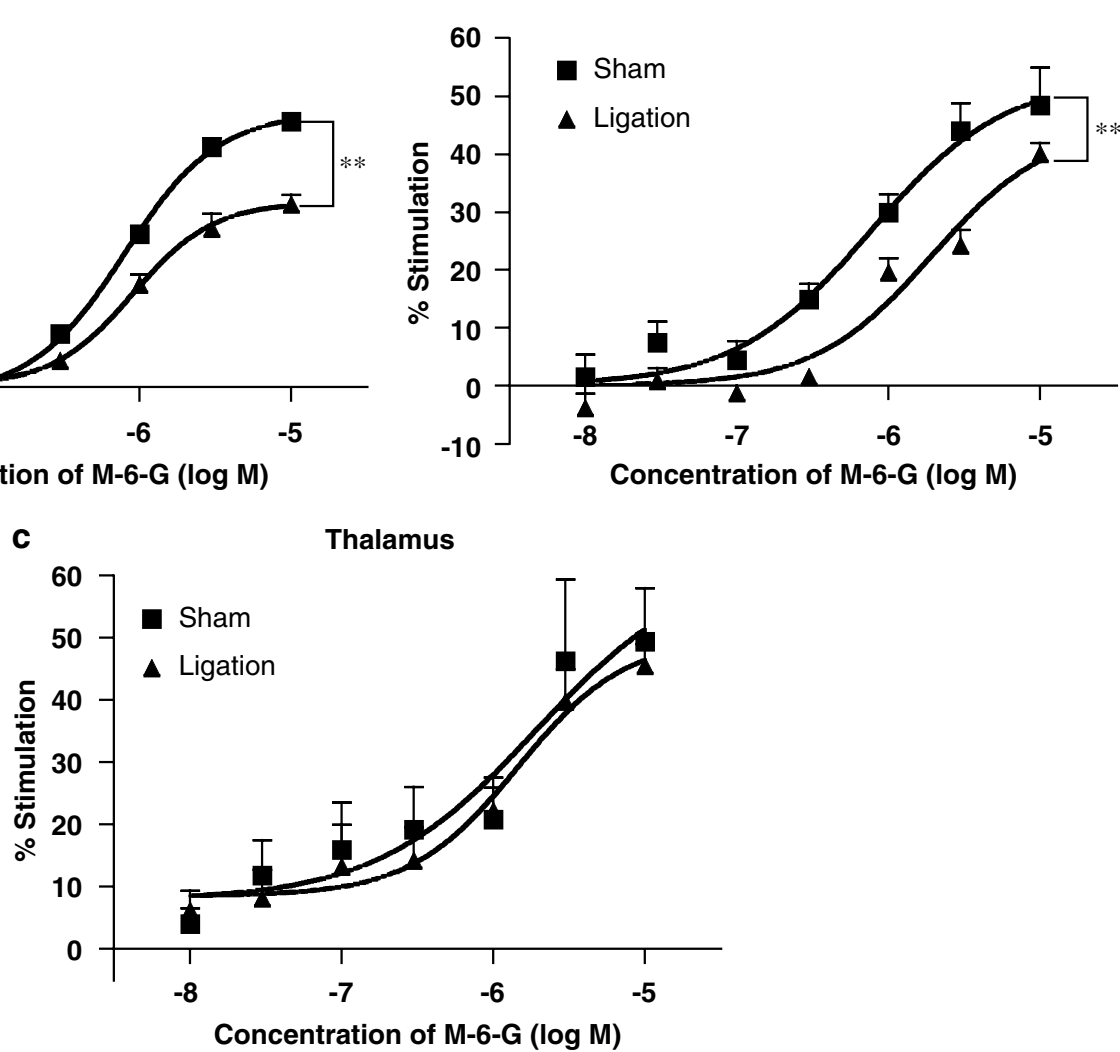

Figure 10 Concentration-response curve of $M-6-G$ on the binding of $\left.{ }^{35} \mathrm{~S}\right] \mathrm{GTT} \gamma \mathrm{S}$ to membranes of the spinal cord (a), PAG (b), or thalamus (c) obtained from sham-operated and sciatic nerve-ligated mice. Membranes were prepared at 7 days after nerve ligation. Each value represents the mean \pm SEM of four to six samples. $* *$ $p<0.0$ I vs sham group.

Suzuki et al, 1999; Zhao et al, 2004). Additionally, it has been reported that i.t. administration with morphine provides analgesia in patients with neuropathic pain syndromes (Krames 2002). Considering these reports, we propose here that the discrepancy and the effectiveness of morphine may be partly related to the timing of the treatment relative to the duration of the neuropathy.

It is well known that morphine is rapidly converted into two metabolites, M-3-G and M-6-G. Approximately, $10 \%$ of morphine is metabolized to $\mathrm{M}-6-\mathrm{G}$ and $50 \%$ is metabolized to M-3-G. The fact that M-3-G has very low affinity for MOR and appears to lack significant analgesic activity suggests that M-6-G may be the only active metabolite of morphine. Several studies support the idea that M-6-G directly contributes to the analgesic effects of morphine (Sawe et al, 1985; Silva et al, 2000; Kilpatrick and Smith, 2005). Therefore, we next investigated the antinociceptive effect of M-6-G in nerve-ligated mice. S.c.-, i.t.-, and i.c.v. administration of $M-6-G$ each induced a marked antinociceptive effect in sham-operated mice. Interestingly, M-6-G-induced antinociceptive effect following each injection was significantly attenuated in nerve-ligated mice compared with that in sham-operated mice. In addition, the concentrationdependent increases in the binding of $\left[{ }^{35} \mathrm{~S}\right] \mathrm{GTP} \gamma \mathrm{S}$ to membranes obtained from the spinal cord and PAG, but not thalamus, stimulated by $M-6-G$ were significantly decreased in nerve-ligated mice compared with those in sham-operated mice. It is considered that morphine in the brain and spinal cord cannot be converted into $M-3-G$ or M-6-G. These findings suggest that the downregulation of M-6-G-sensitive MOR in the spinal cord or PAG area by sciatic nerve injury may result in the suppression of the antinociceptive effect induced by s.c. injection of morphine in nerve-ligated mice.

It has been reported that s.c.-administered oxycodone is metabolized in the liver, and a large proportion of oxycodone is metabolized to noroxycodone and oxymorphone by way of $\mathrm{N}$-demethylation and $\mathrm{O}$-demethylation in the first pass. Current evidence suggests that the metabolites of oxycodone including noroxycodone and oxymorphone do not significantly contribute to its pharmacological effects (Heiskanen and Kalso, 1997). It has been described that both oxymorphone and noroxycodone were more potent than oxycodone after i.t. administration (Lemberg et al, $2006 \mathrm{a}, \mathrm{b})$. In the present study, the increased $\left[{ }^{35} \mathrm{~S}\right] \mathrm{GTP} \gamma \mathrm{S}$ binding induced by oxycodone in membrane fractions of the spinal cord, PAG, and thalamus and the antinociception induced by s.c.-, i.c.v.-, and i.t. administration of oxycodone were not changed by sciatic nerve ligation compared with those in sham-operated mice. Although it remains to be seen the discrepancy of the report regarding the antinociception of metabolites of oxycodone, the present data provide evidence that oxycodone may be a useful alternative to morphine in the treatment of neuropathic pain.

Another key finding in the present study is that the rewarding effects of s.c.-administered morphine or oxyco- 

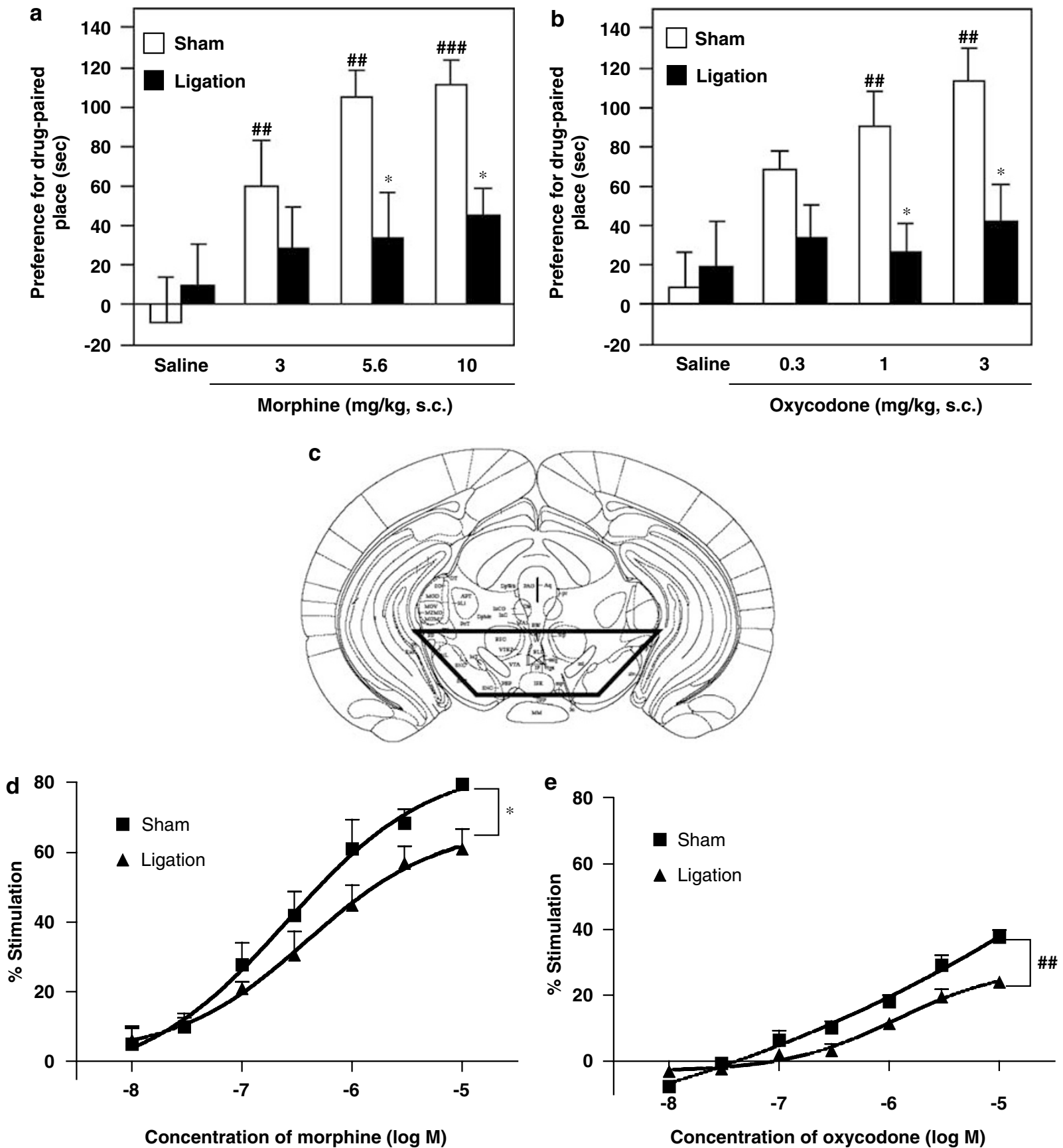

Figure II Conditioned place preference produced by s.c. administration of morphine (3-10 mg/kg, a) or oxycodone $(0.3-3 \mathrm{mg} / \mathrm{kg}$, b) in sham-operated and sciatic nerve-ligated mice using the conditioned place preference paradigm. Ordinate: mean difference between time spent in the post-conditioning test and pre-conditioning test. Immediately after s.c. injection of morphine or oxycodone, mice were placed and conditioned in either compartment for I h. Each column represents the mean \pm SEM of seven to eight mice. ${ }^{\# \#} p<0.01$, \#\#\# $p<0.001$ vs sham-saline group. ${ }^{*} p<0.05$ vs sham-morphine or sham-oxycodone group. According to Paxions' atlas (200I), the coronal brain block of the lower midbrain area (box) was dissected obtained from 2.5 to $4.5 \mathrm{~mm}$ posterior to bregma (c). Effects of morphine (d) or oxycodone (e) on the binding of $\left.{ }^{35} \mathrm{~S}\right] \mathrm{GTP} \gamma \mathrm{S}$ to membranes of the lower midbrain obtained from sham-operated and sciatic nerve-ligated mice. Membranes were prepared 7 days after nerve ligation. Each value represents the mean \pm SEM of four samples. $* p<0.05$ and ${ }_{\# \#} p<0.01$ vs sham group.

done under a neuropathic pain-like state were suppressed following sciatic nerve ligation. The mesolimbic dopaminergic system, which projects from the VTA of the midbrain to the nucleus accumbens (N.Acc.), has been identified as the critical substrate of the reinforcing effects of opioids (Funada et al, 1995; Garzon and Pickel, 2001; Narita et al, 2001c). Considering these findings, we next assessed changes in the ability of morphine or oxycodone to activate G-proteins in the lower midbrain area including the VTA of sham-operated and sciatic nerve-ligated mice by monitoring the binding of $\left.{ }^{35} \mathrm{~S}\right] \mathrm{GTP} \gamma \mathrm{S}$ to membranes. The increase in the binding of $\left[{ }^{35} \mathrm{~S}\right] \mathrm{GTP} \gamma \mathrm{S}$ to lower midbrain membranes 
in nerve-ligated mice stimulated by morphine or oxycodone was significantly lower than that observed in sham-operated mice. We previously reported that intra-VTA administration of DAMGO caused a dose-dependent preference for drug-associated place (Narita et al, 2001c). We also demonstrated that the enhancement of DA release in the N.Acc. stimulated by morphine was significantly suppressed by sciatic nerve ligation (Ozaki et al, 2002). Furthermore, we reported that sciatic nerve ligation caused a dramatic reduction in the activities of extracellular signal-regulated kinase in the tyrosine hydroxylase-positive dopaminergic neuron of the VTA (Ozaki et al, 2004). These findings suggest that the reduction in MOR-mediated G-protein activation in the lower midbrain area caused by sciatic nerve ligation may be responsible for inhibiting the rewarding effects induced by both morphine and oxycodone under a neuropathic pain-like state.

In conclusion, these findings provide further evidence that treatment with oxycodone produces a profound antinociceptive effect under a neuropathic pain-like state, with a less or less of a rewarding effect. Furthermore, the reduction in G-protein activation induced by $M-6-G$ in the spinal cord and PAG may, at least in part, contribute to the suppression of the antinociceptive effect produced by morphine under a neuropathic pain-like state.

\section{ACKNOWLEDGEMENTS}

This work was supported by a research grant from the Ministry of Education, Culture, Sports, Science and Technology of Japan. We thank Dr Yoshinori Yajima, Keisuke Hashimoto, Ayumi Ozeki and Daiki Okutsu for their expert technical assistance.

\section{DISCLOSURE/CONFLICT OF INTEREST}

The authors declare that, expect for income received from our primary employer, no financial support or compensation has been received from any individual or corporate entity over the past 3 years for research or professional service and there are no personal financial holdings that could be perceived as constituting a potential conflict of interest.

\section{REFERENCES}

Bostrom E, Simonsson US, Hammarlund-Udenaes M (2006). In vivo blood-brain barrier transport of oxycodone in the rat: indications for active influx and implications for pharmacokinetics/pharmacodynamics. Drug Metab Dispos 34: 1624-1631.

Funada M, Suauki T, Misawa M (1995). Role of mesolimbic dopamine system in morphine dependence. Ann Psychiatry 5: 222-237.

Garzon M, Pickel VM (2001). Plasmalemmal m-opioid receptor distribution mainly in nondopaminergic neurons in the rat ventral tegmental area. Synapse 41: 311-328.

Haley MJ, McCormick WG (1957). Pharmacological effects produced by intracerebral injections of drugs in the conscious mouse. Br J Pharmacol 12: 12-15.

Hao JX, Yu W, Wiesenfeld-Hallin Z, Xu XJ (1998). Treatment of chronic allodynia in spinally injured rats: effects of intrathecal selective opioid receptor agonists. Pain 75: 209-217.
Heiskanen T, Kalso E (1997). Controlled-release oxycodone and morphine in cancer related pain. Pain 73: 37-45.

Hylden JLK, Wilcox GL (1980). Intrathecal morphine in mice: a new technique. Eur J Pharmcol 67: 313-316.

Kilpatrick GJ, Smith YW (2005). Morphine-6-glucuronide: actions and mechanisms. Med Res Rev 25: 521-544.

Krames E (2002). Implantable devices for pain control: spinal cord stimulation and intrathecal therapies. Best Pract Res Clin Anaesthesiol 16: 619-649.

Le Bars D, Gozriu M, Cadden SW (2001). Animal models of nociception. Pharmacol Rev 53: 597-652.

Lee YW, Chaplan SR, Yaksh TL (1995). Systemic and supraspinal, but not spinal, opiates suppress allodynia in a rat neuropathic pain model. Neurosci Lett 199: 111-114.

Lemberg K, Kontinen VK, Viljakka K, Kylanlahti I, Yli-Kauhaluoma J, Kalso E (2006b). Morphine, oxycodone, methadone and its enantiomers in different models of nociception in the rat. Anesth Analg 102: 1768-1774.

Lemberg KK, Kontinen VK, Siiskonen AO, Viljakka KM, YliKauhaluoma JT, Korpi ER et al (2006a). Antinociception by spinal and systemic oxycodone: why dose the route make a difference? Anesthesiology 105: 801-812.

Malmberg A, Basbaum AI (1998). Partial sciatic nerve injury in the mouse as a model of neuropathic pain: behavioral and neuroanatomical correlates. Pain 76: 215-222.

Mayer DJ, Mao J, Holt J, Price DD (1999). Cellular mechanisms of neuropathic pain, morphine tolerance, and their interactions. Proc Natl Acad USA 96: 7731-7736.

Narita M, Funada M, Suzuki T (2001c). Regulations of opioid dependence by opioid receptor types. Pharmacol Ther 89: $1-15$.

Narita M, Imai S, Ozaki S, Suzuki M, Narita M, Suzuki T (2003). Reduced expression of a novel $\mu$-opioid receptor (MOR) subtype MOR-1B in CXBK mice: implication of MOR-1B in the expression of MOR-mediated responses. Eur J Neuroscience 18: 3193-3198.

Narita M, Kishimoto Y, Ise Y, Yajima Y, Misawa K, Suzuki T (2005a). Direct evidence for the involvement of the mesolimbic kappa-opioid system in the morphine-induced rewarding effect under an inflammatory pain-like state. Neuropsychopharmacology 30: 111-118.

Narita M, Mizoguchi H, Narita M, Nagase H, Suzuki T, Tseng LF (2001b). Involvment of spinal protein kinase $\mathrm{C} \gamma$ in the attenuation of opioid $\mu$-receptor-mediated G-protein activation after chronic intrathecal administration of $\left[\mathrm{D}-\mathrm{Ala}^{2}, \mathrm{~N}-\mathrm{MePhe}^{4}\right.$, Gly-Ol ${ }^{5}$ ] enkephalin. J Neurosci 21: 3715-3720.

Narita M, Mizoguchi H, Suzuki T, Narita M, Dun NJ, Imai S et al (2001a). Enhanced mu-opioid responses in the spinal cord of mice lacking protein kinase Cgamma isoform. J Biol Chem 276: 15409-15414.

Narita M, Usui A, Narita M, Niikura K, Nozaki H, Khotib J et al (2005b). Protease-activated receptor-1 and platelet-derived growth factor in spinal cord neurons are implicated in neuropathic pain after nerve injury. J Neurosci 25: 10000-10009.

Narita M, Yajima Y, Aoki T, Ozaki S, Narita M, Mizoguchi H et al (2000). Up-regulation of the TrkB receptor in mice injured by the partial ligation of the sciatic nerve. Eur J Pharmacol 401: 187-190.

Nichols ML, Michael DB, Ossipov MH, Lai J, Porreca F (1995). Regulation of morphine antiallodynic efficacy by cholecystokinin in a model of neuropathic pain in rats. J Pharmacol Exp Ther 275: 1339-1345.

Ohsawa M, Narita M, Mizoguchi H, Suzuki T, Tseng LF (2000). Involvement of spinal protein kinase $\mathrm{C}$ in thermal hyperalgesia evoked by partial sciatic nerve ligation, but not by inflammation in mice. Eur J Pharmacol 403: 81-85.

Ossipov MH, Lopez Y, Nichols ML, Bian D, Porreca F (1995). The loss of antnociceptive efficacy of spinal morphine in rats with 
nerve ligation injury is prevented by reducing spinal afferent drive. Neurosci Lett 199: 87-90.

Ozaki S, Narita M, Narita M, Iino M, Sugita J, Matsumura Y et al (2002). Suppression of the morphine-induced rewarding effect in the rat with neuropathic pain: implication of the reduction in $\mu$-opioid receptor functions in the ventral tegmental area. J Neurochem 82: 1192-1198.

Ozaki S, Narita M, Narita M, Ozaki M, Khotib J, Suzuki T (2004). Role of extracellular signal-regulated kinase in the ventaral tegmental area in the suppression of the morphine-induced rewarding effect in mice with sciatic nerve ligation. J Neurochem 88: 1389-1397.

Peckham ME, Tratnor JR (2006). Comparison of the antinociceptive response to morphine and morphine-like compounds in male and female Sprague-dawley rats. J Pharmacol Exp Ther 361: 1195-1201.

Paxions G, Franklin KBJ (2001). The Mouse Brain in Stereotaxic Coordinates, 2nd edn. Academic Press: San Diego.

Porreca F, Tang QB, Bian D, Riedl M, Elde R, Lai J (1998). Spinal opioid mu receptor expression in lumbar spinal cord of rats following nerve injury. Brain Res 795: 197-203.

Ross FB, Smith MT (1997). The intrinsic antinociceptive effects of oxycodone appear to be $\kappa$-opioid receptor mediated. Pain 73: 151-157.

Satthl C, Christrup LL, Andersen SD, Arendt-Nielsen L, Drewes AM (2006). A comparative study of oxycodone and morphine in a multi-model, tissue-differentiated experimental pain model. Pain 123: 28-36.

Sawe J, Kager L, Svensson EJO, Rane A (1985). Oral morphine in cancer patients: in vivo kinetics and in vitro hepatic glucuronidation. Br J Clin Pharmacol 19: 495-501.

Seltzer Z, Dubner R, Shi Y (1990). A novel behavioral model of neuropathic pain disorders produced in rats by partial sciatic nerve injury. Pain 43: 205-218.
Siddall PJ, Gray M, Rutkowski S, Cousins MJ (1994). Intrathecal morphine and clonidine in the management of spinal cord injury pain: a case report. Pain 59: 147-148.

Silva RM, Rossi GC, Mathis JP, Standifer KM, Pasternak GW, Bodnar RJ (2000). Morphine and morphine-6 $\beta$-glucuronideinduced feeding are differentially reduced by G-protein asubunit antisense probes in rats. Brain Res 876: 62-75.

Suzuki R, Chapman V, Dickenson AH (1999). The effectiveness of spinal and systemic morphine on rat dorsal horn neuronal responses in the spinal nerve ligation model of neuropathic pain. Pain 80: 215-228.

Suzuki T, Kishimoto Y, Misawa M (1996). Formaline- and carrageenan-induced inflammation attenuates place preferences produced by morphine, methamphetamine and cocaine. Life Sci 59: 1667-1674.

Suzuki T, Kishimoto Y, Misawa M, Nagase H, Takeda F (1999). Role of the kappa-opioid system in the attenuation of the morphine-induced place preference under chronic pain. Life Sci 64: PL1-PL7.

Suzuki T, Kishimoto Y, Ozaki S, Narita M (2001). Mechanism of opioid dependence and interaction between opioid receptors. Eur J Pain 5(Suppl A): 63-65.

Tunblad K, Jonsson EN, Hammarlund-Udenaes M (2003). Morphine blood-brain barrier transport is influenced by probenecid co-administration. Pharm Res 20: 618-623.

Vaccarino AL, Marek P, Kest B, Ben-Eliyasu S, Couret Jr LC, Kao B et al (1993). Morphine failes to produce tolerance when administered in the presence of formalin pain in rats. Brain Res 627: 287-290.

Watson CPN, Babul N (1998). Efficacy of oxycodone in neuropathic pain. A randomized trial in postherpetic neuralgia. Neurology 50: 1837-1841.

Zhao C, Tall JM, Meyer RA, Raja SN (2004). Antiallodynic effects of systemic and intrathecal morphine in the spared nerve injury model of neuropathic pain in rats. Anesthesiology 100: 905-911. 